\title{
Meridional march of diurnal rainfall over Jakarta, Indonesia, observed with a C-band Doppler radar: an overview of the HARIMAU2010 campaign
}

\author{
Shuichi Mori ${ }^{1 *} \mathbb{D}$, Jun-Ichi Hamada ${ }^{1,2}$, Miki Hattori ${ }^{1}$, Pei-Ming Wu' ${ }^{1}$, Masaki Katsumata ${ }^{1}$, Nobuhiko Endo ${ }^{1,3}$, \\ Kimpei Ichiyanagi ${ }^{1,4}$, Hiroyuki Hashiguchi ${ }^{5}$, Ardhi A. Arbain ${ }^{6,7}$, Reni Sulistyowati ${ }^{6}$, Sopia Lestari ${ }^{6,8}$, Fadli Syamsudin ${ }^{6}$, \\ Timbul Manik ${ }^{9}$ and Manabu D. Yamanaka ${ }^{10,11}$
}

\begin{abstract}
This paper presents an overview of the HARIMAU2010 campaign focusing on convective activity with the diurnal rainfall meridional march (DRMM) over Jakarta, which is located on the northern coast of Jawa Island of the Indonesian maritime continent (IMC), based on 1-month intensive observations by a C-band Doppler radar and multi-point atmospheric sounding array conducted during 16 January-14 February 2010. The campaign period corresponded to a phase after large-scale Madden-Julian oscillation (MJO) active convections passed over Jakarta (MJO inactive phase). The cross-equatorial northerly surge (CENS) intruded into the Jawa Sea with a cold tongue (CT) of sea surface temperature (SST) in the beginning of the period (CENS active period: 16-26 January), and then, it started to retreat (transition period: 27 January-05 February); afterward, only a few signs of it were apparent (CENS inactive period: 06-14 February). The observational results showed that (1) rainfall over Jakarta has the nature of DRMM during the MJO inactive phase at least, (2) the DRMM is likely driven primarily by "land-breeze"-like local meridional circulation, and (3) the meridional spatiotemporal variation of rainfall over Jakarta is thus controlled by activities of both the CENS and CT over the Jawa Sea.
\end{abstract}

Keywords: Indonesian maritime continent (IMC), Land-sea breeze circulation, Diurnal cycle, Cross-equatorial northerly surge (CENS), Madden-Julian Oscillation (MJO), Cold tongue (CT)

\section{Introduction}

The Indonesian maritime continent (IMC) lies along the equator and has a zonal width of more than $5000 \mathrm{~km}$. It is composed of various-sized islands with massive orography and complicated coastlines, which are surrounded by oceans with high sea surface temperature (SST). Consequently, a substantial amount of rainfall is produced over the IMC by various kinds of convective activities both in time and space. These convective activities play a major role as an energy source that drives the Walker and Hadley circulations through released heat and moisture

\footnotetext{
* Correspondence: morishu@jamstec.go.jp

1Japan Agency for Marine-Earth Science and Technology (JAMSTEC), 2-15

Natsushima-cho, Yokosuka 237-006, Japan

Full list of author information is available at the end of the article
}

transport (Ramage 1968). Satellite observations have shown that the spatial distribution of tropical rainfall is not homogeneous, and it tends to be well concentrated in "coastal regions," which can be defined as regions within a distance of $300 \mathrm{~km}$ from the coastlines (Ogino et al. 2016, 2017). For example, a coastal heavy rainband ( $\mathrm{CHeR})$ formed by diurnally developed convections along the western coastline of Sumatera Island, Indonesia, was identified clearly by satellite and radar observations (Mori et al. 2011). Thus, the IMC with its long coastlines receives more substantial rainfall amounts than those over other regions in the tropical lands and open oceans.

Diurnally developed convections and local circulations over the IMC have been studied widely, in particular over equatorial western Sumatera Island (e.g., Wu et al. 
2003, 2009a; Mori et al. 2004, 2006, 2011; Sakurai et al. 2005, 2009, 2011; Shibagaki et al. 2006a; Hamada et al. 2008; Kawashima et al. 2011) and in relation to intraseasonal variations (ISVs) including the Madden-Julian oscillation (MJO, Madden and Julian 1972) (e.g., Shibagaki et al. 2006b; Fujita et al. 2011; Kamimera et al. 2012). These studies were based on a number of campaignrelated observations that were collected by using X-band Doppler radars, intensive atmospheric soundings, rain gauge networks, disdrometers, and surface weather stations, as well as satellite observations. Results from those previous studies have shown the nature of diurnal landsea migrations of precipitating systems, their variations with the MJO, and seasonal migration patterns; furthermore, such works resulted in the climatological identification of the CHeR along the southwestern coastline of Sumatera. Recently, Yokoi et al. (2017) examined the mechanism of a diurnal migrating precipitating system along the southwestern coastline of Sumatera by using mainly intensive atmospheric soundings and both shipboard and ground-based C-band radars during November-December 2015 for a preliminary campaign of the Years of the Maritime Continent (YMC); the results of their research implied that there is a crucial role of offshore preconditioning by gravity waves. See Yamanaka (2016) and Yamanaka et al. (2018) for more comprehensive reviews of field observational studies over the IMC.

Jakarta, the capital megacity of Indonesia located in the northwestern "coastal region" of Jawa Island, Indonesia (Fig. 1), has frequently suffered from serious floods in the downtown areas and landslides in the mountain foothill regions caused by torrential rainfall events, which occurred mainly during the boreal winter season from December to February (Wu et al. 2007, 2013; Trilaksono et al. 2011, 2012; Sulistyowati et al. 2014); this timeframe corresponds to the primary rainy season around Jakarta (e.g., Hamada et al. 2002, 2012). Therefore, it is crucial to clarify the environmental conditions associated with torrential rainfall events and obtain a better understanding of the generation and development mechanisms to ensure the socioeconomic security of the coastal megacity Jakarta, as well as to contribute to the current meteorological and climatological points of view. Wu et al. (2007) conducted case studies of torrential rainfall that occurred in January-February 2007 around Jakarta based on the Quick Scatterometer (QuikSCAT) sea surface winds and both operational sounding and radar observation data. They found that these events were generated by the interaction between cross-equatorial northerly surges (CENSs) intruding into the Jawa Sea from the Northern Hemisphere (Hattori et al. 2011) and local circulations over Jakarta, which were closely related to diurnally developed convections over mountain foothill regions in southern Jakarta. In addition, convective activities over the IMC are known to be significantly affected by eastward traveling synoptic disturbances of the MJO or ISV. A case study of the extreme rainfall that occurred during January 2013 over Jakarta showed that an active phase of the MJO approaching the IMC played an essential role in the development of long-lasting convections, which were generated by interactions between the CENS in the Jawa Sea and diurnal local circulations over Jawa Island (Wu et al. 2013). Furthermore, Trilaksono et al. $(2011,2012)$ examined the same case as Wu et al. (2007) by using the Japan Meteorological Agency (JMA)/ Meteorological Research Institute (MRI)-nonhydrostatic model (JMA/MRI-NHM: Saito et al. 2006) and suggested the importance of a cold anomaly in the lower troposphere associated with the CENS, which may be essential for generating the extreme rainfall that results in serious flooding in Jakarta; notably, there was fine horizontal resolution in the model simulations, which allowed them to resolve the complicated topography and diurnally developed local circulations.

Early in the observation history, van Bemmelen (1922) first examined diurnal variations of local winds over Batavia (the old name for the capital Jakarta in the Dutch colonial era) scientifically based on pilot balloon observations in 1905-1915 and found a pronounced land-sea circulation in the lower troposphere that showed a predominant northerly sea breeze in daytime below a height of $1 \mathrm{~km}$ with a counter southerly flow above and a comparatively weak southerly land breeze in reverse during the nighttime to the early morning period. Since then, the local winds, namely, land-sea circulations, and their relation to convective activity over Jakarta have been widely studied by Hashiguchi et al. (1995a, 1995b, 1995c), Hadi et al. (2000, 2002), Renggono et al. (2001), and Araki et al. (2006). These works were conducted by using an L-band wind profiling radar (WPR, also named as a boundary layer radar (BLR)), which was located at Serpong (Fig. 1b) in the southern part of the "greater Jakarta" region (Jakarta city and surrounding urban agglomerations of Jakarta, Bogor, Depok, Tangerang, and Bekasi (JABODETABEK); hereafter, just referred to as Jakarta) shown as the area surrounded by a solid blue line in Fig. 1b. These researchers thoroughly examined the nature of these circulations and possible mechanisms, although the data obtained were basically limited to only vertical measurements at one place rather than spatiotemporal images from the Geostationary Meteorological Satellite (GMS). Recently, Realini et al. (2014) and Oigawa et al. (2017) examined the spatiotemporal variation of precipitable water vapor (PWV) and its relation to diurnally developed convections by using a multi-point global satellite navigation system (GNSS) over Jakarta and Bandung, as well as C-band and $\mathrm{X}$-band radars, respectively. In addition, numerical 

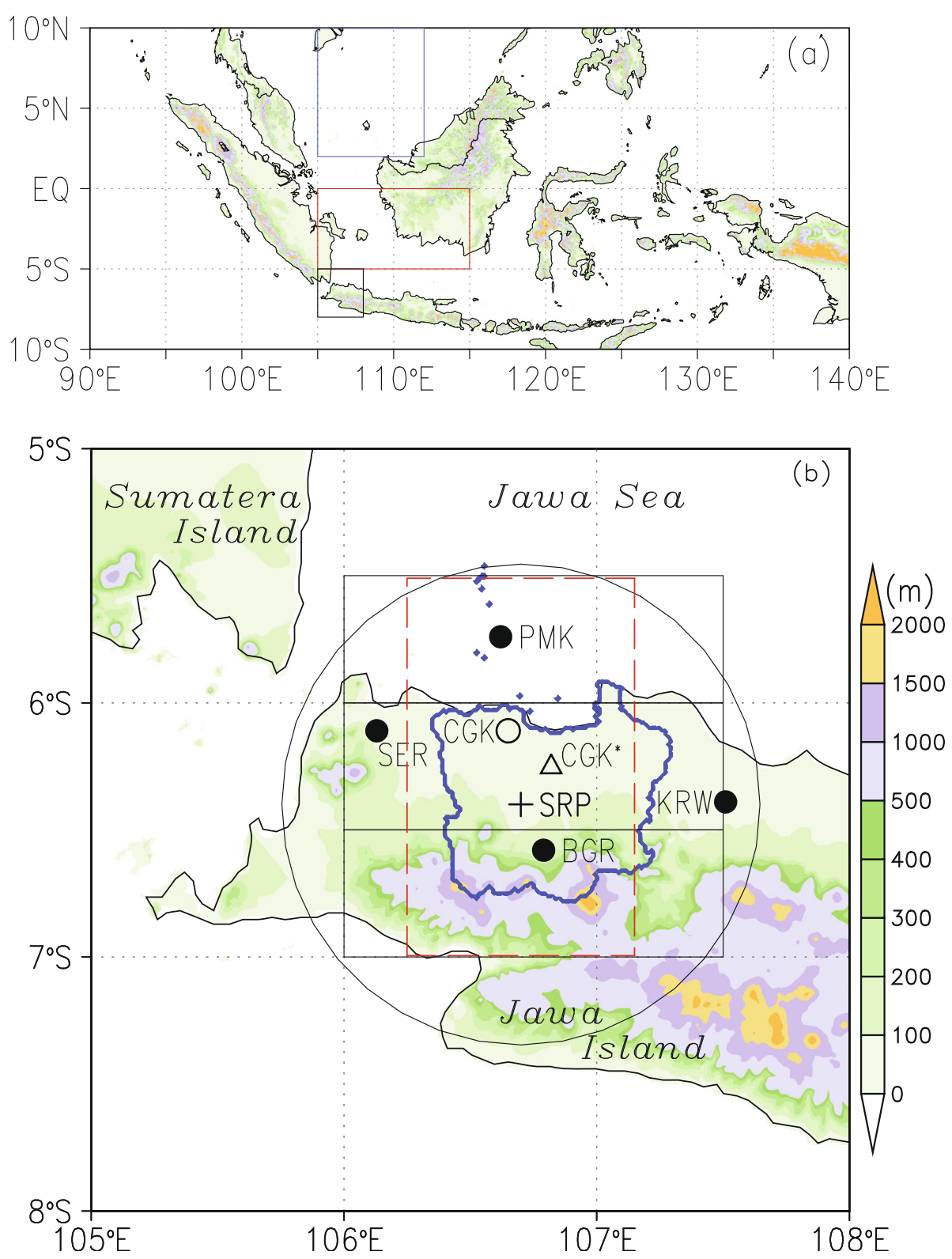

Fig. 1 Area of study for the HARIMAU2010 campaign. a Topographical maps of Indonesia and $\mathbf{b}$ the western part of Jawa Island. Rectangles in black, red, and blue solid lines in panel $\mathbf{a}$ indicate a location in panel $\mathbf{b}$, definition areas for CENS $\left(5.0^{\circ} \mathrm{S}-\mathrm{EQ}, 105^{\circ} \mathrm{E}-115^{\circ} \mathrm{E}\right)$, and definition areas for $C T\left(2^{\circ} \mathrm{N}-10^{\circ} \mathrm{N}, 105^{\circ} \mathrm{E}-112^{\circ} \mathrm{E}\right)$, respectively. The four closed black circles indicate the sounding stations used in the present study: PMK, SER, KRW, and BGR stand for Pramuka, Serang, Karawang, and Bogor, respectively. A small open circle shows the location of the Cengkareng (CGK) BMKG meteorological station for the Jakarta Soekarno-Hatta International Airport. The middle point between Serang and Karawang is indicated as Cengkareng* (CGK*) with an open triangle, and it was used for the analyses in Figs. 7 and 9. SRP with a plus sign stands for Serpong, where both the C-band Doppler radar (CDR) and wind profiling radar (WPR) are installed; the large open circle indicates the observational range (105 km in radius) of the CDR volume scan mode. Large three rectangles depicted by solid black lines over Jakarta $\left(106.0^{\circ} \mathrm{E}-107.5^{\circ} \mathrm{E}\right)$ indicate the areas for GSMaP rain analyses in Fig. 3, which included coastal sea $\left(6.0^{\circ} \mathrm{S}-5.5^{\circ} \mathrm{S}\right)$, land $\left(6.5^{\circ} \mathrm{S}-6.0^{\circ} \mathrm{S}\right)$, and mountain foothill $\left(7.0^{\circ} \mathrm{S}-6.5^{\circ} \mathrm{S}\right)$ regions. The rectangle depicted by the dashed red lines indicates the area $\left(7.0^{\circ} \mathrm{S}-5.5^{\circ} \mathrm{S}, 106.25^{\circ} \mathrm{E}-107.15^{\circ} \mathrm{E}\right)$ for $\mathrm{CDR}$ data analyses in Figs. 6, 7, 8, and 9. The area surrounded by a solid blue line shows the "greater Jakarta" region (Jakarta city and surrounding urban agglomerations of Jakarta, Bogor, Depok, Tangerang, and Bekasi (JABODETABEK); hereafter, just referred to as Jakarta)

model simulations have been utilized to diagnose interactions between local winds, namely, land-sea circulations and diurnally developed convections over Jakarta, and the results implied a vital role of the CENS or cold tongue (CT) of SST over the South China Sea (SCS) in generating active convections at the land-breeze front, in particular for nocturnal heavy precipitation around the coastal region (Trilaksono et al. 2011, 2012; Koseki 
et al. 2012); however, no spatiotemporal radar or in situ observational data have been examined yet.

As the final campaign of the 5-year Japan Earth Observation System (EOS) Promotion Program (JEPP)-Hydrometeorological Array for ISV-Monsoon Automonitoring (HARIMAU) project (2005-2010, Yamanaka et al. 2008), we have carried out an integrated observation study, named HARIMAU2010 from 00 UTC (coordinated universal time) on 16 January 2010 to 24 UTC on 14 February 2010 (30 days) during the major rainy season over Jakarta. As shown in Fig. 1b, we deployed a C-band Doppler radar (CDR), intensive atmospheric sounding network, and surface weather stations during the campaign period so as to investigate the nature and spatiotemporal variation of convective activities that can generate torrential rainfall over Jakarta as well as those interactions among the MJO, CENS, and CT. This paper provides an overview of the HARIMAU2010 campaign and examines the spatiotemporal variation of diurnally developed convections over Jakarta by focusing on their relation to local circulations as the first case study based on CDR observations with a multi-point sounding array.

\section{Methods/Experimental}

Figure 1 shows the topography of the western part of Jawa Island along with the locations of observational sites for this study, which are described in detail in the following subsections. Jakarta is located at the most northern tip of a plain extending between the mountain range and Jawa Sea to the south and north, respectively. Averaged precipitation over the region is approximately $2000 \mathrm{~mm} \mathrm{year}^{-1}$ and $400 \mathrm{~mm}$ month $^{-1}$ in the rainy season (Hamada et al. 2012). Local time (LT) used in this study represents West Indonesian standard time (WIB) over the western part of Indonesia (WIB meridian: $\left.105^{\circ} \mathrm{E}\right)$ including Jakarta $(\mathrm{LT}=\mathrm{UTC}+7 \mathrm{~h})$. Therefore, the sunrise (sunset) time over Jakarta is approximately 06 (18) LT throughout the year.

\section{C-band Doppler and wind profiling radars}

We employed the CDR and WPR installed at Serpong $\left(6.40^{\circ} \mathrm{S}, 106.70^{\circ} \mathrm{E}, 46 \mathrm{~m}\right.$ above mean sea level (AMSL)) to observe the behaviors of convections over Jakarta and wind profiles, respectively, with high temporal and spatial resolutions. Major specifications of the CDR and WPR are summarized in Table 1 . The CDR obtains the three-dimensional reflectivity and Doppler velocities every 6 min through a series of conical scans with antenna elevations ranging from $0.6^{\circ}$ to $50^{\circ}$ (volume scan mode) and surveillance observations at one elevation angle $\left(0.6^{\circ}\right)$. Observation radii of the CDR were $105 \mathrm{~km}$ (Fig. 1b) and $175 \mathrm{~km}$ for the volume scan mode and surveillance observations, respectively, and only the former data were examined in the present study.
Table 1 Major specifications of Serpong CDR and WPR, and their operating condition during the HARIMAU2010 campaign

\begin{tabular}{|c|c|c|}
\hline Parameter & & Value \\
\hline Radar & $\begin{array}{l}\text { C-band } \\
\text { Doppler radar } \\
\text { (CDR) }\end{array}$ & $\begin{array}{l}\text { Wind profiling radar } \\
\text { (WPR) }\end{array}$ \\
\hline Location & \multicolumn{2}{|c|}{ Serpong $\left(6.40^{\circ} \mathrm{S}, 106.70^{\circ} \mathrm{E}, 46 \mathrm{~m}\right.$ AMSL) } \\
\hline $\begin{array}{l}\text { Manufacturer } \\
\text { and model }\end{array}$ & $\begin{array}{l}\text { Toshiba } \\
\text { Corporation } \\
\text { JMA-237B }\end{array}$ & $\begin{array}{l}\text { Sumitomo Electric Industries } \\
\text { (SEI) WPR LQ-0 (with } \\
\text { 3-Parabolic Antennas) }\end{array}$ \\
\hline Frequency & $5.320 \mathrm{GHz}$ & $1357.5 \mathrm{MHz}$ \\
\hline Peak power & 140 kW & $400 \mathrm{~W}$ \\
\hline Pulse width & $1.0 \mu \mathrm{s}$ & $0.67 \mu \mathrm{s}$ \\
\hline \multirow{2}{*}{$\begin{array}{l}\text { Pulse } \\
\text { repetition } \\
\text { frequency } \\
\text { (PRF) }\end{array}$} & $\begin{array}{l}1800 \mathrm{~Hz} \\
\text { (surveillance) }\end{array}$ & $10 \mathrm{kHz}$ \\
\hline & $\begin{array}{l}1360 \mathrm{~Hz} \\
\text { (volume scan) }\end{array}$ & \\
\hline Beam width & $0.98^{\circ}$ & $7.6^{\circ}$ \\
\hline $\begin{array}{l}\text { Signal } \\
\text { processor }\end{array}$ & Sigmet RVP8 & SEI LQ \\
\hline \multirow[t]{2}{*}{$\begin{array}{l}\text { Maximum } \\
\text { range }\end{array}$} & $\begin{array}{l}175 \mathrm{~km} \\
\text { (surveillance) }\end{array}$ & 0.3-10 km (vertically) \\
\hline & 105 km (volume scan) & \\
\hline $\begin{array}{l}\text { Sampling } \\
\text { resolution }\end{array}$ & $200 \mathrm{~m}$ & $100 \mathrm{~m}$ \\
\hline $\begin{array}{l}\text { Antenna } \\
\text { rotation speed }\end{array}$ & $30^{\circ} \mathrm{s}^{-1}$ & - \\
\hline \multirow[t]{2}{*}{$\begin{array}{l}\text { Elevation } \\
\text { angles }\end{array}$} & $\begin{array}{l}0.6^{\circ} \\
\text { (surveillance) }\end{array}$ & $\begin{array}{l}\text { Beam directions (Az, Ze) }\left(0^{\circ}, 0^{\circ}\right) \text {, } \\
\left(0^{\circ}, 15^{\circ}\right),\left(90^{\circ}, 15^{\circ}\right)\end{array}$ \\
\hline & $\begin{array}{l}0.6^{\circ}-50.0^{\circ} \\
\text { (18 elev./volume scan) }\end{array}$ & \\
\hline Scan interval & $6 \mathrm{~min}$ & $1 \mathrm{~min}$ \\
\hline
\end{tabular}

Data obtained by the CDR were first processed by the Sigmet "interactive radar information system (IRIS)" (Vaisala 2008), and the following three signal filters were applied: "log receiver signal-to-noise ratio (LOG)," "clutter-to-signal ratio (CSR)," and "signal quality index (SQI)." Range bins with LOG $<1.0 \mathrm{~dB}, \mathrm{CSR}<23 \mathrm{~dB}$, and SQI $<0.4$ were omitted as "no data," which is where reflectivity was below the noise level and Doppler velocity was not available. Then, the IRIS "speckle filter" was applied to remove isolated data bins that must not have been weather targets, for example, towers and aircrafts. Atmospheric gaseous attenuation was corrected by $0.0016 \mathrm{~dB} \mathrm{~km}^{-1}$ as the IRIS default setting, whereas rain attenuation was not applied to the obtained data because only qualitative rain distributions were analyzed in the present study and no quantitative discussions were presented ${ }^{1}$ for example, comparisons with ground-based rain gauge data or satellite-derived rainfall data. The area between $6.83^{\circ} \mathrm{S}$ and $6.72^{\circ} \mathrm{S}$ was disregarded from the analyses because of the serious ground clutter below 
$2 \mathrm{~km}$ AMSL caused by the mountain range in the southern part of Jawa Island, as shown in Fig. 1.

The reflectivity and radial Doppler velocity were interpolated over the Cartesian coordinates with grid intervals of $0.5 \mathrm{~km}(421$ grids $\times 421$ grids in a $105 \mathrm{~km} \times$ $105 \mathrm{~km}$ square) in the horizontal and $0.5 \mathrm{~km}$ in the vertical (40 levels from 0.5 to $20 \mathrm{~km} \mathrm{AMSL}$ ) plane for this study. Reflectivity fields were partitioned into convective and stratiform regions by using a technique proposed by Steiner et al. (1995). We calculated the hourly rainfall rates from the reflectivity field by using $Z-R$ relations for each rainfall type, where $Z$ and $R$ are the radar reflectivity $(\mathrm{dBZ})$ and rainfall rate $\left(\mathrm{mm} \mathrm{h}^{-1}\right)$, respectively. In this study, we employed the $\mathrm{Z}-\mathrm{R}$ relations as first-guess values for rainfall rate estimations in the Tropical Rainfall Measuring Mission (TRMM) 2A25 version 5 algorithm, i.e., $Z=148 \mathrm{R}^{1.55}$ for convective rainfall, $Z=276 R^{1.49}$ for stratiform rainfall (Schumacher and Houze Jr., 2003), to facilitate comparisons of the rainfall characteristics among various regions. Then, the rainfall rates were averaged over the maximum volume-scan coverage area to estimate radar echo coverage (\%) in the following analyses. Radar echo coverage was defined as the area of radar echo $\left(\mathrm{km}^{2}\right)$ with a radar reflectivity of more than $10 \mathrm{dBZ}$ at a specific height divided by the area of radar detection $\left(\mathrm{km}^{2}\right)$ at the same height. The CDR data used in the present study started from 09 LT on 17 January 2010 because of electrical troubles and ended at 07 LT on 15 February 2010.

The WPR obtained three components of the wind velocity with high spatiotemporal resolutions (see Table 1) during the campaign period successfully. The WPR data were valuable for analyzing the fine structures of the wind distribution in and out of mesoscale convections around the Serpong WPR site as a number of previous studies have showed, e.g., Hashiguchi et al. (1995a, 1995b, 1995c), Hadi et al. (2000), Renggono et al. (2001), and Araki et al. (2006). However, the WPR data were not analyzed in this paper because these data were not suitable for direct comparisons with spatiotemporally averaged CDR and atmospheric sounding array data over the "greater Jakarta" region, which are mentioned later in detail.

\section{Intensive atmospheric soundings}

We made intensive soundings from 00 UTC on 16 January to 24 UTC on 14 February 2010 (30 days) at 6-h intervals and additional 3-hourly soundings from 00 UTC on 24 January to 24 UTC on 06 February 2010 (14 days) at Pramuka $\left(05.74^{\circ} \mathrm{S}, 106.62^{\circ} \mathrm{E}, 1 \mathrm{~m}\right.$ AMSL), Serang $\left(06.11^{\circ} \mathrm{S}, 106.13^{\circ} \mathrm{E}, 71 \mathrm{~m}\right.$ AMSL), Karawang $\left(06.39^{\circ} \mathrm{S}, 107.51^{\circ} \mathrm{E}, 53 \mathrm{~m}\right.$ AMSL), and Bogor $\left(06.58^{\circ} \mathrm{S}, 106.79^{\circ} \mathrm{E}, 248 \mathrm{~m}\right.$ AMSL) to obtain the atmospheric structure at sub-diurnal temporal scales. In addition, we employed operational (00 and 12 UTC) and extra (06 and 18 UTC) sounding data obtained at Cengkareng $\left(06.11^{\circ} \mathrm{S}, 106.65^{\circ} \mathrm{E}, 9 \mathrm{~m}\right.$ AMSL), where there is a meteorological station for the Jakarta Soekarno-Hatta International Airport managed by the Agency for Meteorology, Climatology and Geophysics, Indonesia (BMKG). Locations of sounding stations are depicted in Fig. 1 b, and specifications for the sounding time and types of transmitters, receivers, and balloons are summarized in Table 2. All soundings provided vertical profiles of pressure, temperature, relative humidity, and horizontal wind every $2 \mathrm{~s}$, which corresponded to a height resolution of approximately $10 \mathrm{~m}$, and the data were averaged vertically into $100-\mathrm{m}$ intervals. In addition,

Table 2 Specifications of intensive sounding network during the HARIMAU2010 campaign. (00 UTC 16 January-24 UTC 14 February 2010)

\begin{tabular}{|c|c|c|c|c|c|}
\hline Site name & Bogor & Pramuka & Serang & Karawang & Cengkareng \\
\hline Location & $\begin{array}{l}06.58^{\circ} \mathrm{S} \\
106.79^{\circ} \mathrm{E}\end{array}$ & $\begin{array}{l}05.74^{\circ} \mathrm{S} \\
106.62^{\circ} \mathrm{E}\end{array}$ & $\begin{array}{l}06.11^{\circ} \mathrm{S} \\
106.13^{\circ} \mathrm{E}\end{array}$ & $\begin{array}{l}06.39^{\circ} \mathrm{S} \\
107.51^{\circ} \mathrm{E}\end{array}$ & $\begin{array}{l}06.11^{\circ} \mathrm{S} \\
106.65^{\circ} \mathrm{E}\end{array}$ \\
\hline Height (AMSL) & $248 m$ & $1 \mathrm{~m}$ & $71 \mathrm{~m}$ & $53 \mathrm{~m}$ & $9 \mathrm{~m}$ \\
\hline Sounding time (UTC) & \multicolumn{4}{|c|}{$\begin{array}{c}00,03,06,09,12,15,18 \text { (24 January-06 February) } \\
00,06,12,18 \text { (other period) }\end{array}$} & $\begin{array}{l}00,06 \\
12,18\end{array}$ \\
\hline Missing data period & - & 00 UTC 16-06 UTC 17 January & - & 00 UTC 17-12 UTC 20 January & - \\
\hline Transmitter & \multicolumn{4}{|c|}{ Vaisala RS92-SGPD } & Meisei RS-06C \\
\hline Receiver & \multicolumn{2}{|l|}{$\begin{array}{l}\text { Vaisala } \\
\text { MW15 }\end{array}$} & $\begin{array}{l}\text { Vaisala } \\
\text { MW31 }\end{array}$ & $\begin{array}{l}\text { Vaisala } \\
\text { MW21 (MW15 used until } 18 \text { UTC } 16 \text { January) }\end{array}$ & - \\
\hline AWS & & $\begin{array}{l}\text { Vaisala } \\
\text { MAWS201 }\end{array}$ & & $\begin{array}{l}\text { Davis Weather Monitor II (All data missing due } \\
\text { to troubles) }\end{array}$ & - \\
\hline Disdrometer & $\begin{array}{l}\text { Persivel } \\
\text { M300 }\end{array}$ & - & - & - & - \\
\hline Rainwater sampling & $x$ & $x$ & - & - & - \\
\hline
\end{tabular}


3-hourly interpolated data were created during the 6-hourly sounding period at each station for the following analyses.

We adopted the sounding stations at Pramuka (PMK), Serang (SER), Cengkareng (CGK), Karawang (KRW), ${ }^{2}$ and Bogor (BGR) for representative locations of the "coastal sea" over the Jawa Sea, western, central, and eastern "coastal land," and "mountain foothills" of southern Jakarta, respectively, as shown in Fig. 1b. However, we found serious biases in the operational sounding data collected at Cengkareng, in particular for the relative humidity in the lower troposphere as well as the temperature and wind data. Therefore, we made a composite dataset as a proxy of the soundings at Cengkareng by using those data obtained at both Serang and Karawang, and then, we used it in the following analyses designated as "Cengkareng* $\left(\mathrm{CGK}^{*}\right)$ " at the middle point $\left(06.25^{\circ} \mathrm{S}, 106.82^{\circ} \mathrm{E}\right.$, $62 \mathrm{~m}$ AMSL) between Serang and Karawang (see Fig. 1b), the representative location of "central coastal land." In addition, portions of sounding data in the beginning of the campaign were lacking because of receiver troubles at Pramuka and Karawang (see Table 2 for details).

\section{Surface observations}

Automatic weather stations (AWSs) were deployed at Bogor, Pramuka, Serang, Serpong (Vaisala MAWS201), and Karawang (Davis Weather Monitor II). They provided surface pressure, temperature, relative humidity, solar radiation, wind direction and speed, and rainfall data. The minimum sensitivity for the rainfall amount and the temporal resolution of the recorded data were $0.2 \mathrm{~mm}$ and 1 min, respectively. However, the whole AWS dataset obtained at Karawang was lost during a mechanical malfunction. Raindrop size distribution data were obtained every 1 min with a Parsivel M300 optical disdrometer at Bogor. Moreover, rainwaters were sampled at Pramuka, Bogor, and the Pondok Betung BMKG station (06.25 $\mathrm{S}, 107.61^{\circ}$ E, $26 \mathrm{~m} \mathrm{AMSL}$ ) every 3 or $6 \mathrm{~h}$ for stable isotope analyses (e.g., Fudeyasu et al. 2011; Belgaman et al. 2016), though these data are not examined in this paper.

\section{Other data}

Optimum interpolation sea surface temperature (OISST; Banzon et al. 2016) and blended sea winds (BSW; Zhang et al. 2006) data provided by the U.S. National Oceanic and Atmospheric Administration (NOAA) and objective reanalysis data (Kalnay et al. 1996) supplied by the U.S. National Centers for Environmental Prediction (NCEP) were used to analyze large-scale environmental conditions over the Jawa Sea and Jawa Island during the campaign period. The spatiotemporal resolutions of the OISST and BSW datasets were $0.25^{\circ} \times 0.25^{\circ}$ and 1 day, and those of the NCEP reanalysis were $2.5^{\circ} \times 2.5^{\circ}$ and 1 day. An all-season real-time multivariate MJO (RMM) index (Wheeler and Hendon 2004) provided by the Bureau of the Meteorology Research Centre (BMRC) of Australia was also used to confirm the phases of MJO activity during this period. A global satellite mapping of precipitation (GSMaP; Okamoto et al. 2005) near-real-time (NRT) dataset provided by the Japan Aerospace Exploration Agency (JAXA) was used to examine the temporal and spatial distribution of rainfall over the whole IMC region. In addition, the GTOPO30 (U.S. Geological Survey 1993) global digital elevation model (DEM) dataset with a spatial resolution of 30-min arcseconds was used to confirm the area of radar detection and depict the topography around the study region. Moreover, we made numerical model simulations for experimental near real-time rainfall forecasts over Jakarta with the JMA/MRI-NHM, though those results are not presented in this paper because their reproducibility has not been validated sufficiently for analyses yet.

\section{Results}

Synoptic view during the campaign period

A Hovmöller diagram of the GSMaP rain rate and NCEP wind barbs at $925 \mathrm{hPa}$ during January-February 2010 is shown in Fig. 2 along with a RMM diagram for the same period. Although a large-scale disturbance recognized as a MJO passed over the IMC region in early January, only small-scale and isolated rain areas were identified over western Jawa $\left(106^{\circ}-107^{\circ} \mathrm{E}\right)$ during the campaign period of 16 January-15 February 2010. Westerly wind prevailed over the IMC in the beginning of the campaign period, which blew into the convection center of the $\mathrm{MJO}$ in the east. As a result, the northwestern part of Jawa including Jakarta city was regarded as being in the MJO inactive phase and free from effects caused by such large-scale equatorial disturbances. Indeed, the RMM index (Fig. 2b) showed that the center of the MJO activity passed through the IMC (regions 4-5) by 20 January 2010, and then it reached into the western Pacific Ocean (regions 6-7) in February.

Each panel in Fig. 3 shows (a) temporal variations of the NCEP horizontal wind vectors and meridional wind speed (shade) at $925 \mathrm{hPa}$, (b) the CENS index defined as the area averaged meridional sea surface wind over $105^{\circ}$ $\mathrm{E}-115^{\circ} \mathrm{E}, 5^{\circ} \mathrm{S}-\mathrm{EQ}$ (Hattori et al. 2011) based on BSW data, (c) the CT index defined as the area averaged SST at $2^{\circ} \mathrm{N}-10^{\circ} \mathrm{N}$ and $105^{\circ} \mathrm{E}-112^{\circ} \mathrm{E}$ based on OISST data (Koseki et al. 2012), (d) the area averaged GSMaP daily rainfall over the western part of Jawa including Jakarta shown in the rectangular areas in Fig. 1b, and (e) the CDR echo coverage at a height of $2 \mathrm{~km}$ with the convective echo fraction during the campaign period. As seen in Fig. 3a, CENS originated from the far north (> $\left.20^{\circ} \mathrm{N}\right)$ Siberia-Mongolia area and ran through the East and South China Seas, and then it finally intruded into the northern coastline of Jawa Island $\left(6^{\circ} \mathrm{S}\right)$, with the 

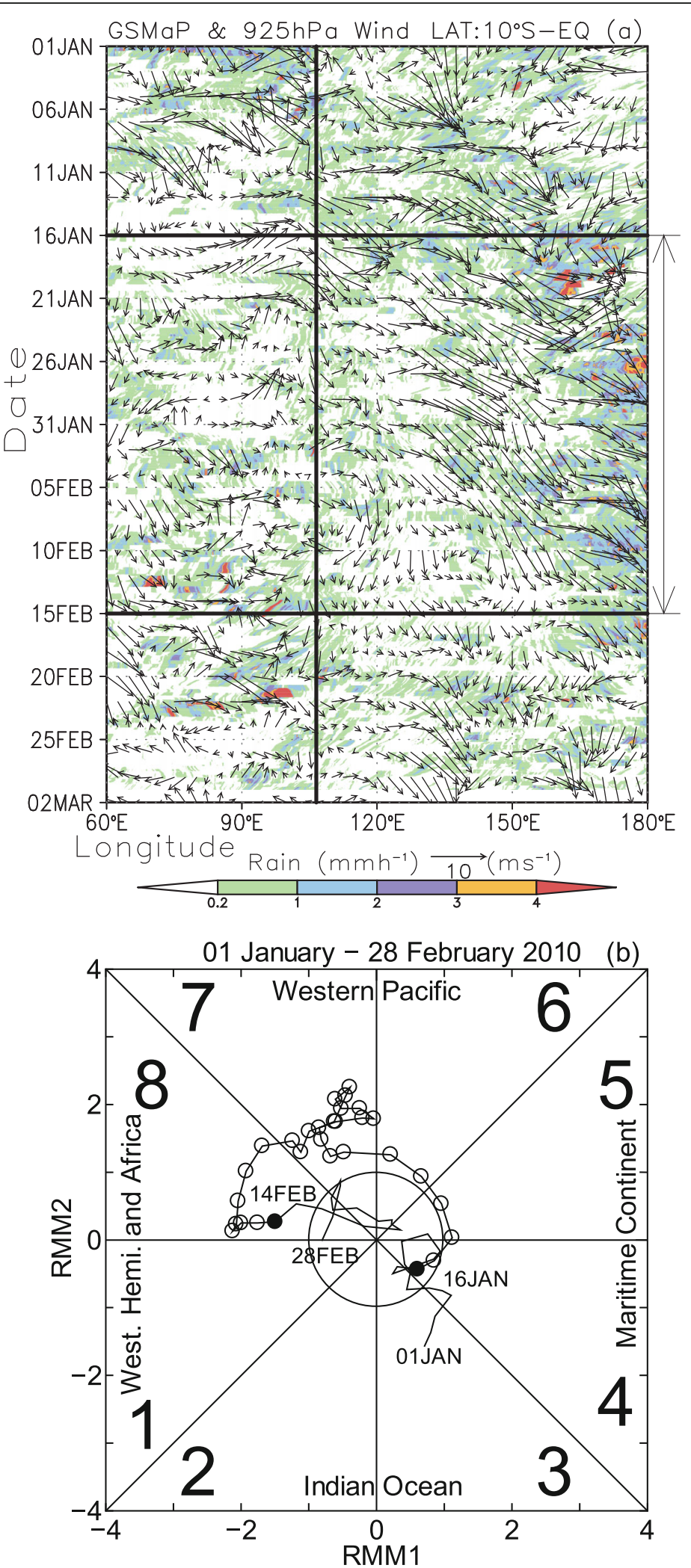

Fig. 2 (See legend on next page.) 
(See figure on previous page.)

Fig. 2 Synoptic disturbances during the campaign period. a Hovmöller diagram of the GSMaP rain intensity with NCEP wind vectors at $925 \mathrm{hPa}$ and $\mathbf{b}$ the RMM index based on data distributed from the BMRC during January and February 2010. The vertical line in panel a indicates the longitudinal location Serpong, Jakarta $\left(106.7^{\circ} \mathrm{E}\right)$. The vertical arrow between the two horizontal lines shows the period of the HARIMAU2010 campaign (16 January-14 February 2010). Open and closed circles in panel $\mathbf{b}$ show daily positions of the MJO center during the campaign period and starting/ending dates of the campaign, respectively

largest negative CENS index at $<-5 \mathrm{~m} \mathrm{~s}^{-1}$ (Fig. 3b; we used the definition of a "CENS event" by Hattori et al. 2011) at the beginning of the campaign (16 January). This was followed by a short break period (19-24 January), and then its strength decreased gradually with time until the end of the campaign (14 February). As a result, moderate northerly wind up to $3-4 \mathrm{~m} \mathrm{~s}^{-1}$ prevailed over Jakarta in the first half of the campaign followed by weak southerly wind less than $2 \mathrm{~m} \mathrm{~s}^{-1}$ in the latter half of the period, though northerly wind was still observed over the Jawa Sea. Simultaneously, the CT index (Fig. 3c) reached its minimum on 17 January and then increased gradually with intermittent minimal peaks. Consequently, the campaign period was regarded as a withdrawal or weakening phase of both the CENS and CT from the synoptic point of view.

Figure $3 \mathrm{~d}$ shows the area averaged daily rainfall over the western part of the Jawa Island, which is divided into the coastal sea (red), land (green), and mountain foothill (gray) regions as shown in Fig. 1b.The daily rainfall over the coastal sea and land regions before the campaign started showed maximums of approximately $60 \mathrm{~mm}$ and $90 \mathrm{~mm}$, respectively, while that over the mountain foothills was below $20 \mathrm{~mm}$. Conversely, the values were comparatively small (i.e., mostly below $20 \mathrm{~mm}$ ) in the former 20 days (16 January-04 February) except on 26 and 29 January over the coastal sea and land regions. On the other hand, the daily rainfall over the mountain foothill region amounted to more than $50 \mathrm{~mm}$ in the latter 10 days (05-14 February) while that over the coastal sea and land regions stayed mostly below $30 \mathrm{~mm}$ and $10 \mathrm{~mm}$, respectively. The total CDR echo coverage (Fig. 3e) in the beginning of the campaign showed diurnal variations with peaks of around 25-40\% until 23 January. The convective echo fraction during the same period had similar variations with peaks below $20 \%$ just in advance of each peak in the total echo coverage. Conversely, diurnal peaks of convective echo fractions after 23 January increased gradually from approximately 20 to $30 \%$ until 13 February when the next northerly wind approached Jawa Island, though they decreased a little over a short period during 28 January and 02 February.

Time-height cross sections of sounding data during the campaign period obtained at Bogor, where the most southern sounding station is located alongside the mountain foothills, are presented in Fig. 4. We first examined the data obtained at Bogor because this was the only station that had no missing data period during the campaign, including for 3-hourly soundings (Table 1), and it was one of the fundamental stations used for further analyses in the following subsections. Although meridional wind in the lower troposphere (Fig. 4d) showed a weak northerly component in the beginning of the period, which was consistent with the sign of the CENS in Fig. 3a, it was not sustainable and was followed by a frequent southerly component by the end of the period. Meanwhile, zonal wind (Fig. 4c) in the lower troposphere showed a westerly velocity of more than $10 \mathrm{~m} \mathrm{~s}^{-}$ ${ }^{1}$ in the beginning of the campaign period, which blew into the MJO convection center located in the western Pacific Ocean as mentioned above. On the other hand, that in the upper troposphere was strong easterly wind, which formed stable vertical wind shear, and this wind was strong in the former half of the period. The westerly wind in the lower troposphere decreased by the end of January and then changed into weak easterly wind in the latter half of the period. This zonal wind regime, i.e., strong westerly, westerly, and easterly winds, also characterized the three sub-periods of the campaign.

Although equivalent potential temperature (Fig. 4a) showed vital diurnal variations throughout the analysis period, it displayed a cold anomaly in the former half of the period followed by a warm anomaly, which occurred 5-10 days in advance of the zonal wind shift in the lower troposphere. The specific humidity (Fig. 4b) showed massive dry layers in the middle troposphere around a height of $5 \mathrm{~km}$ in the beginning (16-20 January) and the end (10-14 February) of the analysis periods as well as diurnal variations in the lower troposphere. Sounding data in the middle to upper troposphere, i.e., above a height of $5 \mathrm{~km}$, which were observed at all five stations, had quite similar synoptic characteristics to those data collected at Bogor (figures not shown) because they were obtained within a horizontal range of $100 \mathrm{~km}$ at maximum (see Fig. 1b). Those in the lower troposphere, however, showed pronouncedly different features from each other in particular from the point of their diurnal variations, which are described in detail in the following subsections.

Based on the results of the synoptic views above, we divided the campaign period into three 10-day subperiods as follows: period-I (16-25 January 2010), period-II (26 January-04 February 2010), and period-III (05-14 February 2010), hereafter referred to as the CENS active, transition, and inactive periods, 

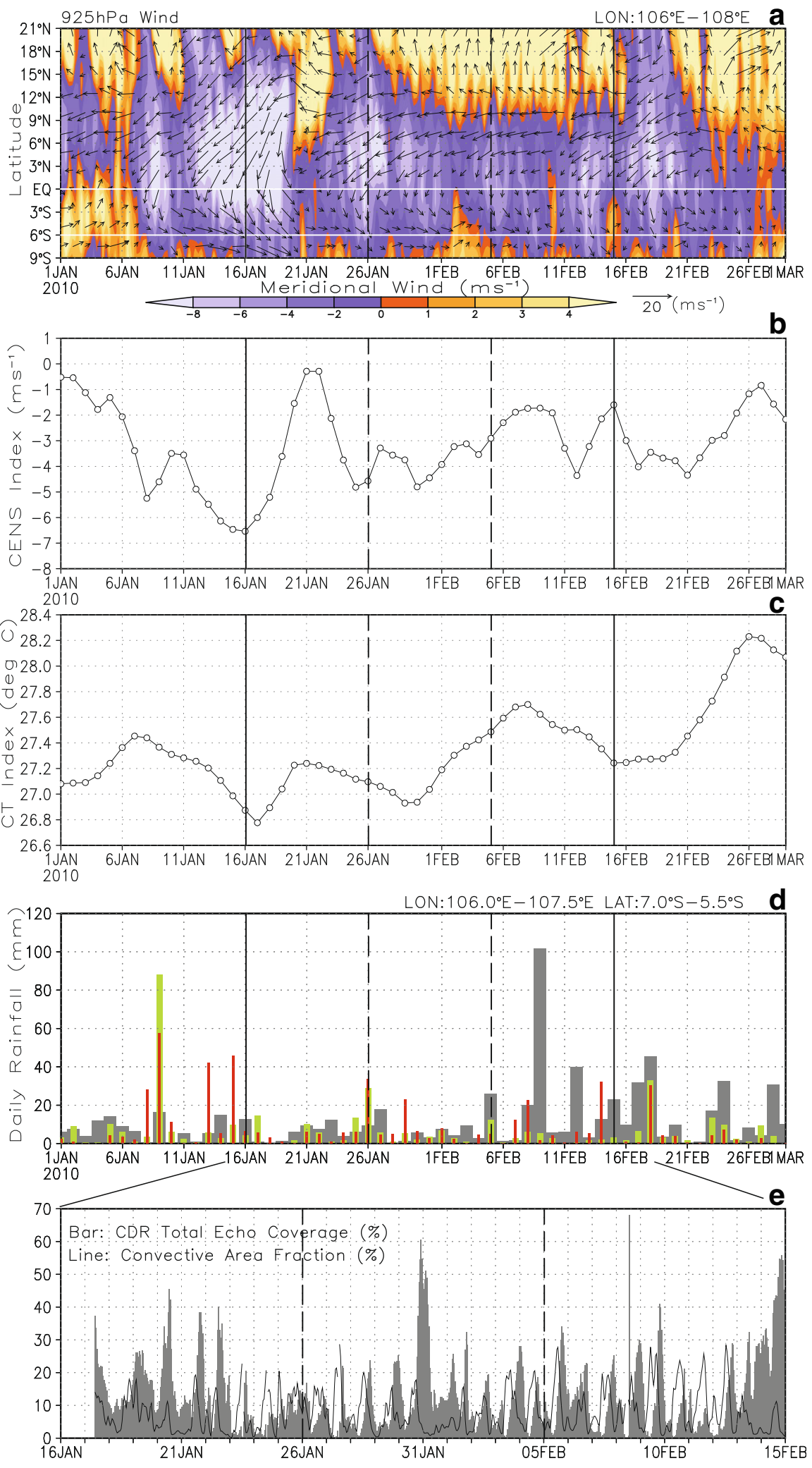

Fig. 3 (See legend on next page.) 
(See figure on previous page.)

Fig. 3 Temporal variations of the CENS, CT, and rainfall during the campaign period. a Temporal variations of NCEP horizontal wind vectors and meridional wind speed (shade) at $925 \mathrm{hPa}$ averaged between $106^{\circ} \mathrm{S}-108^{\circ} \mathrm{E}, \mathbf{b}$ CENS and $\mathbf{c} C \mathrm{C}$ indices, $\mathbf{d}$ the GSMaP daily rainfall amount over Jakarta, and e CDR echo coverages. d The GSMaP rain rate is divided into three regions as designated in Fig. 1b: coastal sea (red), plain (green), and mountain foothills (gray). e Bars (gray) and lines (black) in the CDR echo coverages indicate the total echo coverage (\%) and convective rain area fraction (\%)

respectively, for convenience in the analyses. The CENS and CT indices and brief descriptions of the lower troposphere in each sub-period are summarized in Table 3.

\section{Meridional march of diurnal rainfall over Jakarta and local circulations}

Figure 5 shows the daily and diurnal variations of surface rainfall during the campaign period observed by AWSs at Pramuka (a), Serang (b), Serpong (c), and Bogor (d), which correspond to the north (coastal sea), west (coastal land), central (plain), and south (mountain foothills) areas of the sounding array, respectively, as shown in Fig. 1b. Note that the AWS data at Serang were employed as "coastal land" because there was no AWS installed at Cengkareng and that at Karawang was completely in a no data status during the whole campaign period (see Table 2). Diurnal rainfall over the "coastal sea" observed at Pramuka increased rapidly after sunset around $18 \mathrm{LT}$; its primary peak occurred at $21 \mathrm{LT}$. Then, it decreased gradually until $06 \mathrm{LT}$ with a secondary peak at 03 LT. This diurnal variation seems to be a combination of typical variations over the land with evening showers and over the sea with nocturnal rain. The Pramuka daily rainfall was comparatively large in the middle of the campaign period (25 January-5 February), but not much occurred at both the beginning and ending of the period. The rainfall over the "coastal land" observed at Serang (Fig. 5b) did not show any specific diurnal peaks or daily variations, though there was a slight tendency for more rainfall in the early morning (late evening) in the former (latter) half of the period, whereas that over the "plain" area observed at Serpong (Fig. 5c) showed weaker and gentle diurnal peaks in the afternoon at $12 \mathrm{LT}$ and $16 \mathrm{LT}$ according to period averaged characteristics throughout the whole period without specific daily variations. Conversely, that over the "foothills" observed at Bogor (Fig. 5d) showed a pronounced diurnal variation with a striking peak at around $17 \mathrm{LT}$ as an averaged appearance (right panel), though the peak time varied much day by day during the period. In addition, the daily rainfall amount increased gradually from the beginning to the end of the period with a phase delay of the diurnal rainfall peak from around noon (11 LT) to the evening (18 LT). Similar phase delay features were also seen at the other AWS stations but around differential local times, e.g., at Pramuka (Fig. 5a) from $18 \mathrm{LT}$ to
$03 \mathrm{LT}$ in the beginning to middle of the period, though this was not so clear in comparison with that in Bogor (Fig. 5d). These findings indicate that diurnal and daily rainfall variations over Jakarta have quite different characteristics along the meridional direction perpendicular to the coastline.

We then proceeded to examine the meridional variation of diurnally developed convections during the campaign period, which have been partially reported on by Sulistyowati et al. (2014) as well. Figure 6a shows the meridional variation of the CDR echo distribution at a height of $2 \mathrm{~km}$ over Jakarta averaged over a $100-\mathrm{km}$ width $\left(106.25^{\circ} \mathrm{E}-107.15^{\circ} \mathrm{E}\right)$ in the east-west direction from the CDR site as shown by a rectangle with dashed red lines in Fig. 1b. Note that the width decreases only from $5.6^{\circ} \mathrm{S}(100 \mathrm{~km})$ to $5.5^{\circ} \mathrm{S}(70 \mathrm{~km})$ according to our analysis, and this condition also applies to Figs. 6, 7, 8, and 9. The weak and broad extent of the radar echo was evident in the first quarter of the period, which corresponded to the intrusion of the active CENS (Fig. 3a), and similar echoes were seen in the last few days of the period. A major part of the echo distribution showed pronounced diurnal variation with strong reflectivity in the southern mountainous region in the afternoon and northern coastal region in the nighttime to next early morning. Both major reflectivity regions were connected apparently in some cases from south (north) to north (south) in the late evening (early morning); however, this was not always obvious for the whole period. Therefore, the diurnal variation ( $48 \mathrm{~h}$ for convenience) of the radar echo distribution averaged over the whole campaign period is presented in Fig. 6b, and it was composed of the following three major parts: (1) a large extent of the echo area developed in the daytime to late evening around the mountains on the southern side of Jakarta, (2) northward traveling echoes moved from the mountains to the coastline in the evening (approximately 15 LT) at a speed of approximately $5 \mathrm{~m} \mathrm{~s}^{-1}$, and then they stayed and redeveloped around the coastal region through the night, and (3) some parts of the echoes started to return back southward from the coastal to mountain foothill regions in the morning (approximately $06 \mathrm{LT}$ ) with a speed of approximately $2 \mathrm{~m} \mathrm{~s}^{-1}$, although this was not more obvious than the northward propagation. Note that, however, these are period averaged characteristics created by the superposition of diurnal cycles, which varied much from day to day. Indeed, these 


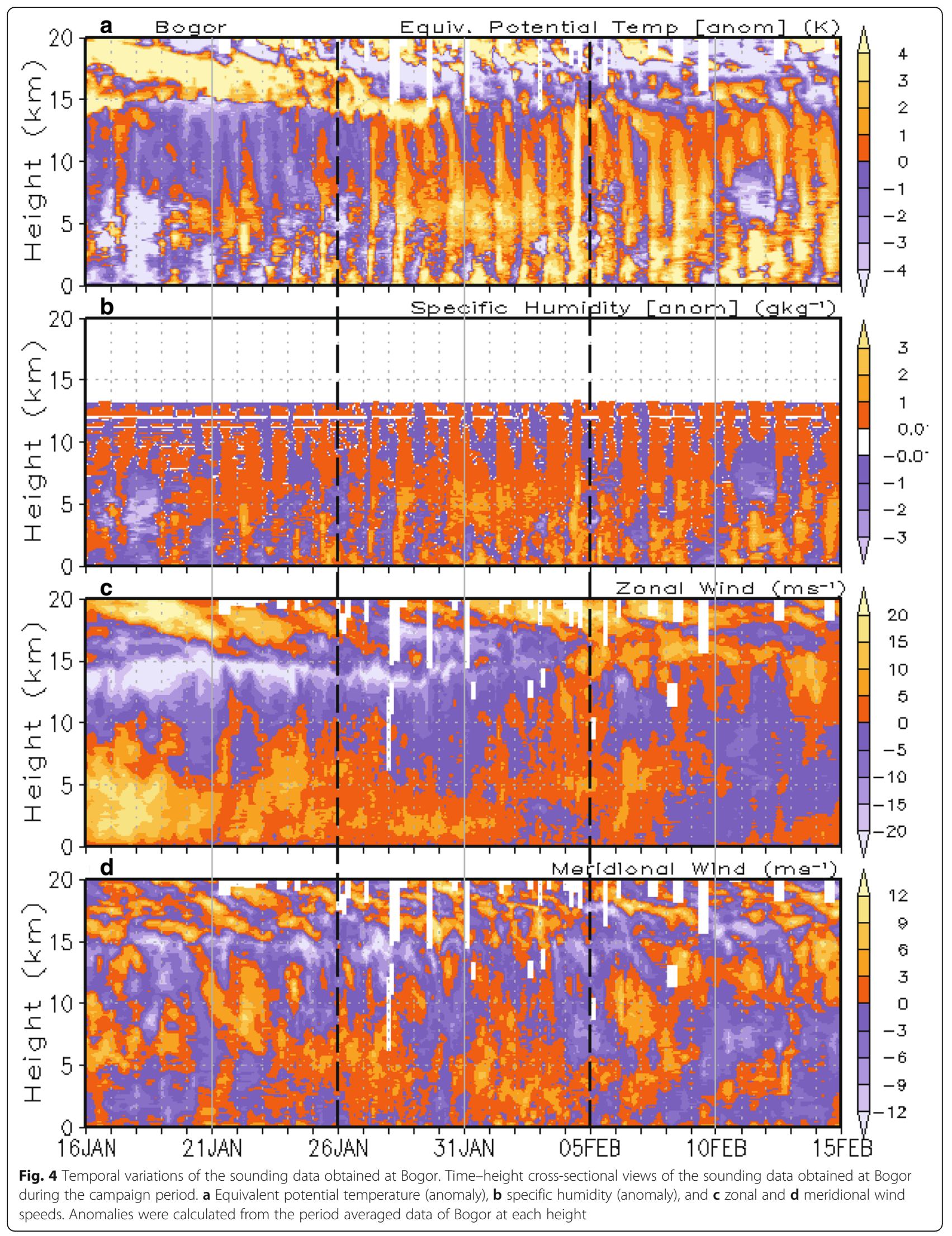


Table 3 Indices and brief descriptions of lower troposphere in each sub-period

\begin{tabular}{llll}
\hline Sub-periods & Period-I (CENS active) & Period-II (transition) & Period-III (CENS inactive) \\
\hline Date & $16-25$ January & 26 January-04 February & $05-14$ February \\
CENS Index [avg] $\left(\mathrm{ms}^{-1}\right)$ & -3.42 & -3.83 & -2.25 \\
CENS Index [min] $\left(\mathrm{ms}^{-1}\right)$ & -6.53 & -4.80 & -4.30 \\
CT Index [avg] (deg.C) & 27.07 & 27.14 & 27.54 \\
CT Index [min] (deg.C) & 26.78 & 26.93 & 27.35 \\
Temperature & Cooler & Getting warmer & Warmer \\
Zonal wind & Strong westerly & Westerly & Easterly \\
Meridional wind & Most northerly & Southerly & Little northerly \\
Remarks & CENS reached its maximum in the & CENS started to retreat accompanied & CENS mostly retreated with \\
& beginning of the sub-period with the & by both warmer CT and atmospheric & the warmest CT and atmospheric \\
& lowest CT, cool atmosphere, and strong & temperature in the lower troposphere & temperature in the lower \\
& westerly wind in the lower troposphere & with decreasing easterly wind. & troposphere followed by \\
& followed by an intermittent break. & & easterly wind. \\
\hline
\end{tabular}

Italicized letter in the CENS Index [min] shows above the criteria of "CENS" by Hattori et al. (2011). See text in detail

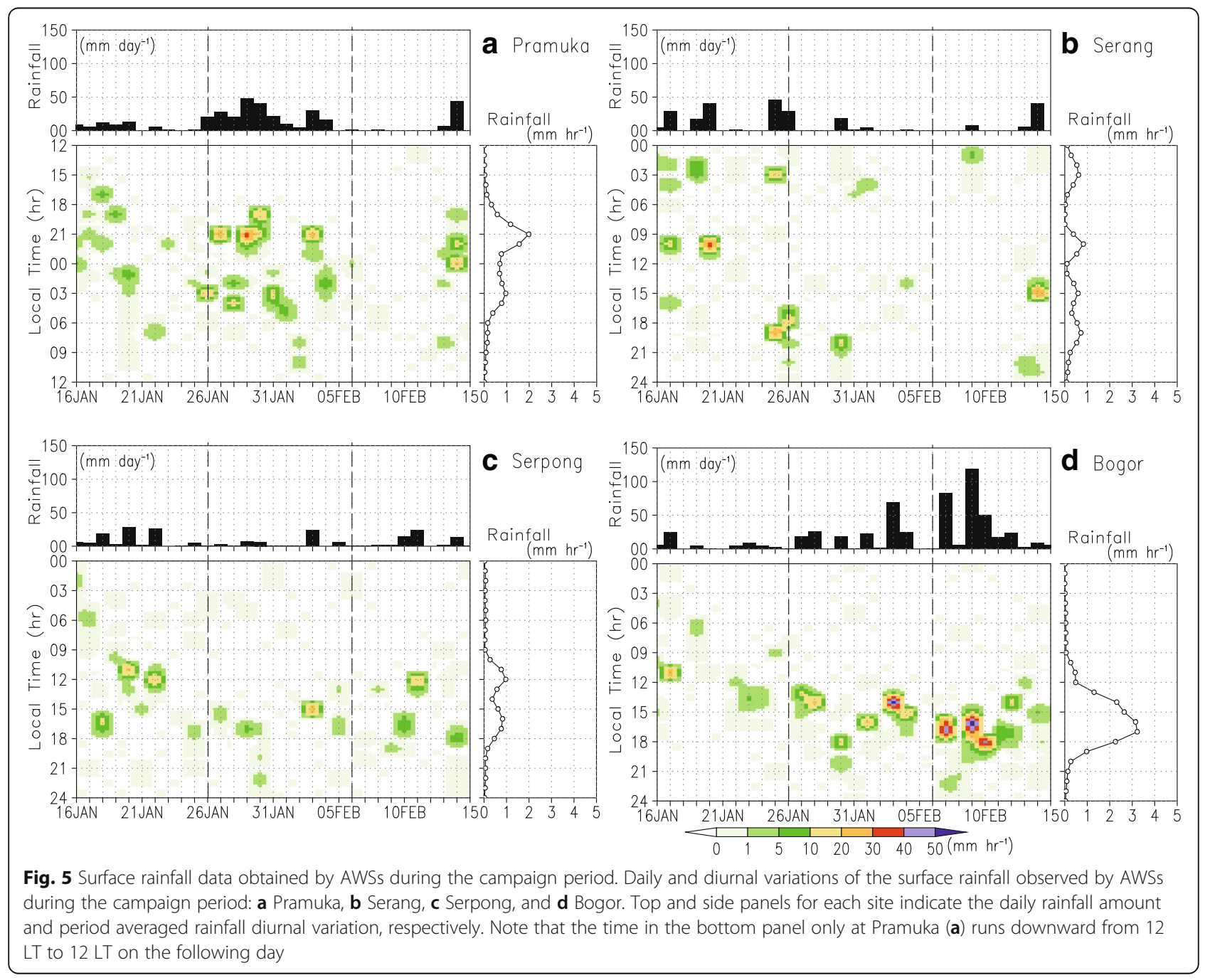




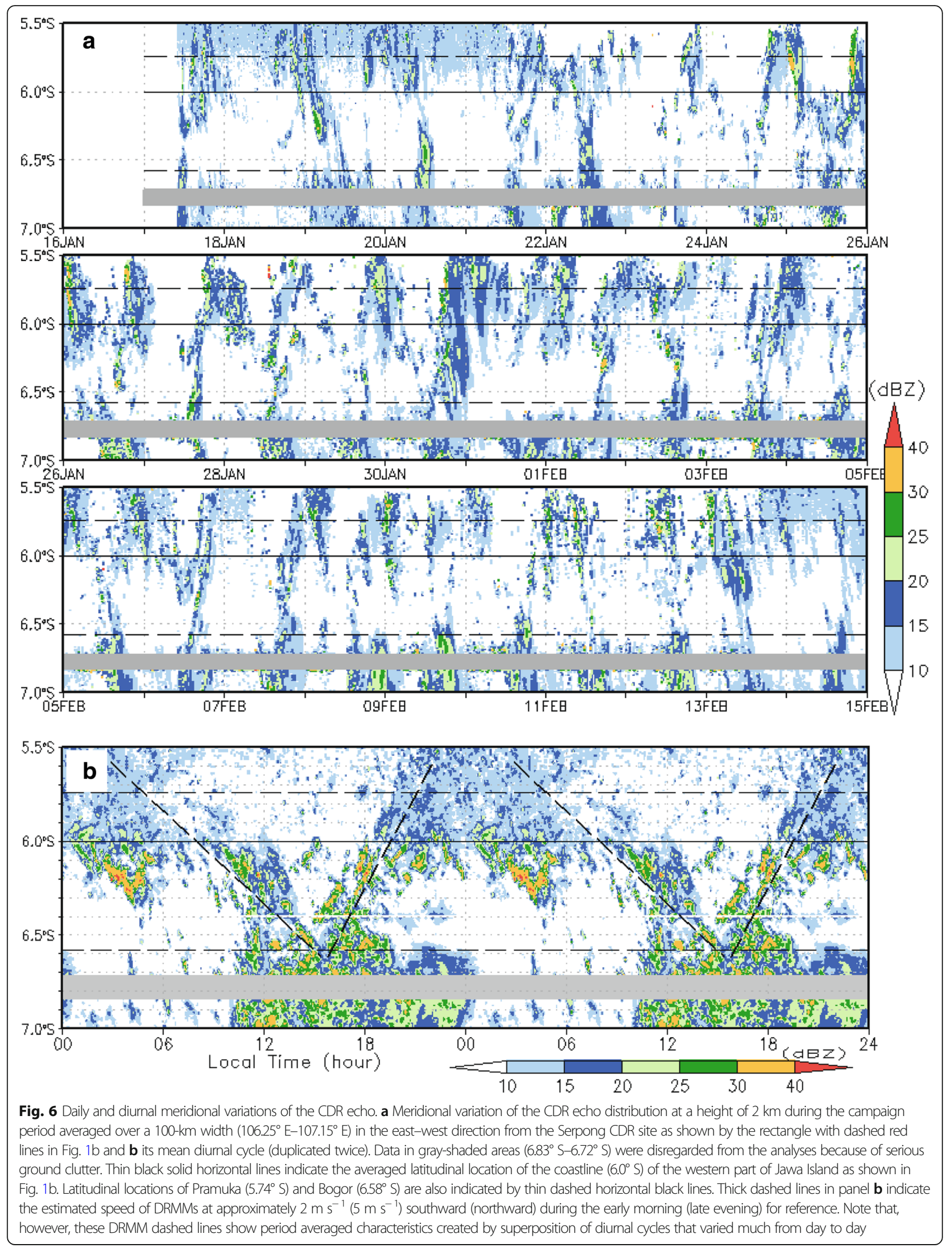




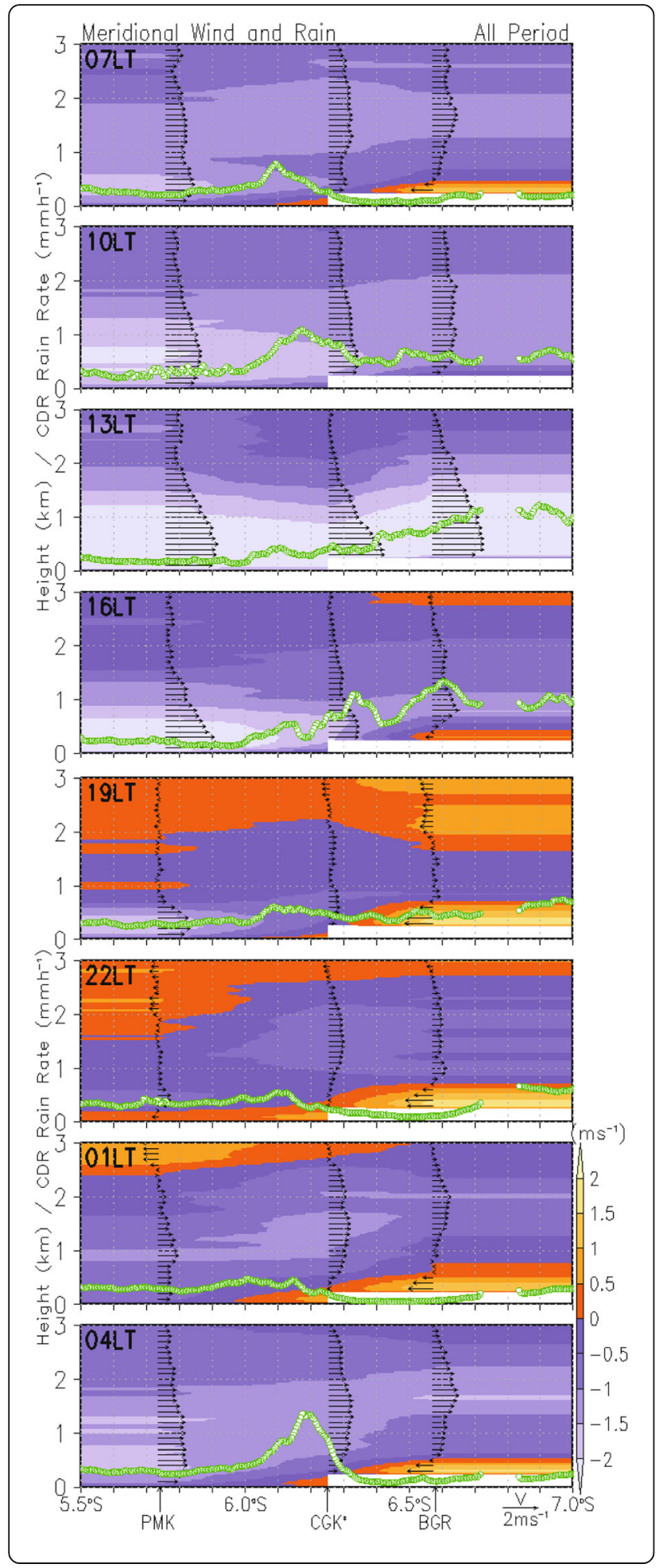

Fig. 7 Diurnal meridional circulations over Jakarta. Cross-sectional views of diurnal meridional circulation over Jakarta obtained by the multi-point sounding array averaged for the campaign period (color shades and wind vectors) with the meridional distribution of the CDR estimated rain rate at a height of $2 \mathrm{~km}$ (green lines with small circles) averaged over a $100-\mathrm{km}$ width in the east-west direction from Serpong. Pramuka, Cengkareng, and Bogor indicate the sounding stations at the coastal sea over the Jawa Sea (north), the coastline (center), and the mountain foothills (south), respectively

characteristics are apparently different among the CENS active, transition, and inactive phases, as shown in Fig. 8, and they should be examined in detail individually as we will do in our next study.

Finally, in this subsection, we examine the diurnal variation of the meridional local circulation over Jakarta and its relation to the rainfall spatial variation, namely, the diurnal rainfall meridional march (hereafter, DRMM). Figure 7 shows cross-sectional views of meridional wind circulation in the lower troposphere perpendicular to the coastline from the "coastal sea (Pramuka)" to the "mountain foothills (Bogor)" through the "coastal land (Cengkareng")" every $3 \mathrm{~h}$ from $07 \mathrm{LT}$ to $04 \mathrm{LT}$ on the following day averaged for the campaign period as well as the area averaged rainfall intensity calculated from the CDR reflectivity observations. Meridional wind at 13 LT showed substantial seabreeze-like northerly wind in the whole lower troposphere below a height of $3 \mathrm{~km}$ from the Jawa Sea to mountain foothills with a maximum close to the surface layer. Rainfall intensity increased gradually from the coastline to foothill region at the same time and reached its daily maximum of approximately $1 \mathrm{~mm} \mathrm{~h}^{-1}$ over the foothills around Bogor. Afterward, a land-breeze-like southerly wind appeared first at $16 \mathrm{LT}$ close to the surface over the foothills and the rainfall intensity over the foothill (coastal land) region started to decrease (increase) simultaneously. The southerly wind near the surface over the land increased its depth and meridional extent after sunset at $19 \mathrm{LT}$, and thus, a frontline formed at the location of the surface northerly wind over the coastal land (Cengkareng*). Most of the rainfall over the foothill and plain regions disappeared at the same time, and another weak and broad rainfall area started to appear instead, which stretched from the coastline to the coastal sea region. Finally, the southerly wind close to the surface reached over the Jawa Sea (Pramuka) at $22 \mathrm{LT}$ at its maximum extent in a day, and then it started to retreat from the coastal sea southward at $01 \mathrm{LT}$ and was balanced with the predominant synoptic northerly wind close to the sea surface. A rainfall peak was generated around the coastline at $04 \mathrm{LT}$ ahead of a front that formed between the intrusion of northerly wind from the Jawa Sea to the coastal land and the retreating land-breeze-like southerly wind. The sea-breeze-like northerly wind developed much after the sunrise during 07-10 LT and covered over the whole study 


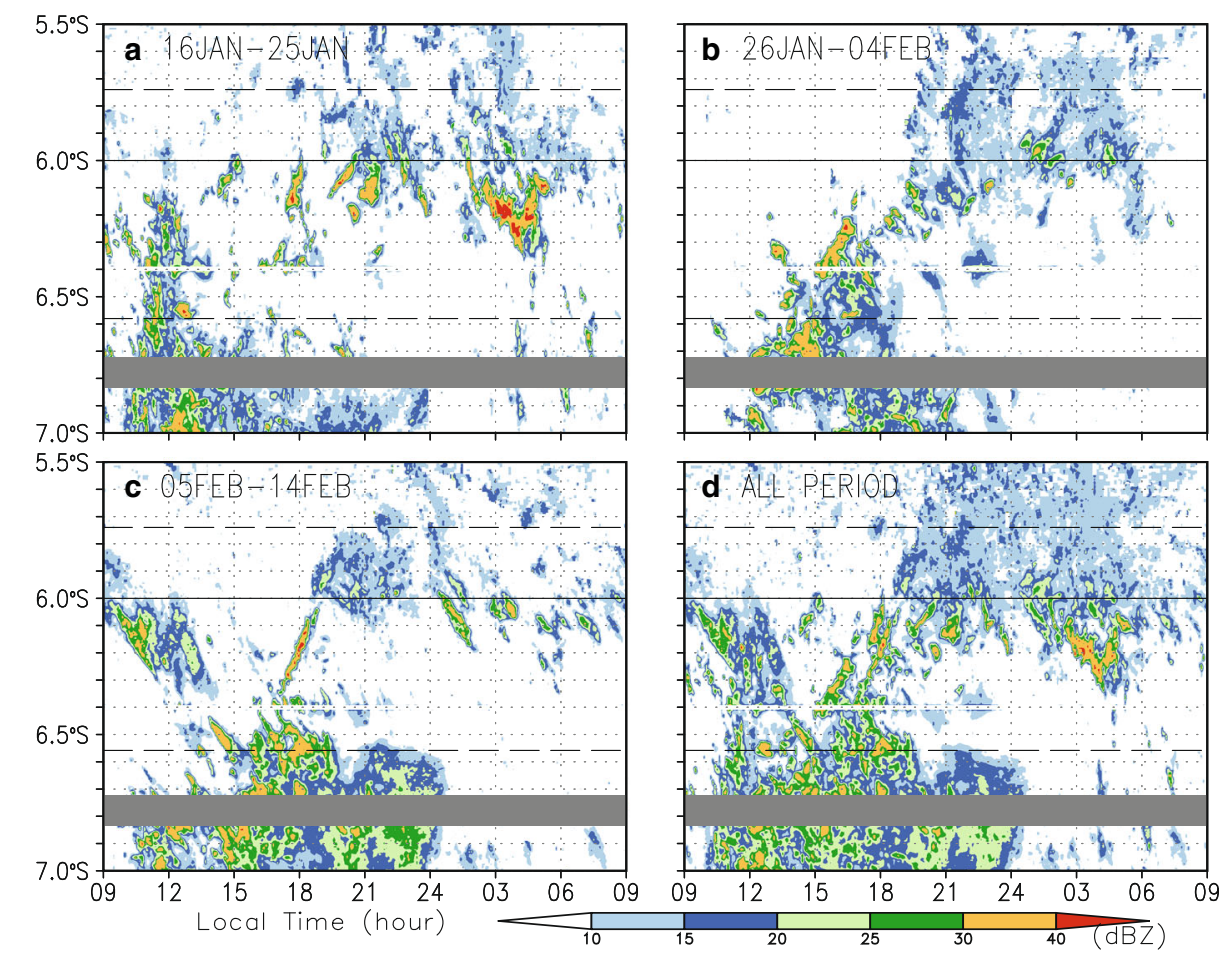

Fig. 8 Diurnal meridional variations of the CDR echo in each period. Same as Fig. 6b but 24-h views of DRMM averaged for the a CENS active, $\mathbf{b}$ transition, and $\mathbf{c}$ inactive periods, as well as the $\mathbf{d}$ whole periods

area quite rapidly, whereas a moderate rainfall area remained over the coastline.

The aforementioned results can be summarized as follows. (1) Most rainfall was generated originally over the mountain foothill region in the area south of Jakarta in the afternoon when the sea breeze was predominant over the whole study region, and then, it decreased with time after reaching a maximum in the evening. (2) Another rainfall event started to form over the "front" of land-breeze-like southerly wind after sunset and traveled toward the north until it reached the diurnal peak over the coastline region in the early morning of the following day. (3) The peak of coastal rainfall decreased with time after sunrise and seemed to be traveling southward as daytime convections developed gradually over the plain and then mountain foothill region by afternoon.

\section{Role of CENS and CT in the DRMM over Jakarta}

Based on the results presented in the last subsection, we found that the diurnal cycle of local meridional circulation along the coastline of the Jawa Sea played an essential role in the formation of DRMM over Jakarta. We next examine how the DRMM over Jakarta varies in response to the CENS with $\mathrm{CT}$ intrusion into or retreat from Jawa Island, which is a fundamental environment for the local meridional circulation. Figure 8 shows the averaged DRMM over Jakarta observed by the CDR, and the data are the same as those in Fig. $6 \mathrm{~b}$ but show the CENS active (a: 16-25 January 2010), transition (b: 26 January-04 February 2010), and CENS inactive (c: 05-14 February 2010) periods.

First, rainfall over the mountain foothill region $\left(6.7^{\circ}\right.$ S-6.4 $4^{\circ}$ ) showed a narrow but not very developed peak at around 12 LT during the CENS active period (Fig. 8a) and there was mostly no rainfall in the late afternoon (15-21 LT), whereas that over the coastal land region around $6.3^{\circ} \mathrm{S}-6.0^{\circ} \mathrm{S}$ was quite active during $18-06 \mathrm{LT}$. Both northward and southward DRMMs were not well identified, and the two major rainfall areas looked separated. Second, rainfall during the CENS transition period (Fig. 8b) over the foothill region increased in its intensity with a peak around $15 \mathrm{LT}$, and then it weakened gradually but was maintained by the evening (18 LT); meanwhile, that over the coastal region showed a weak and broad extent during 19-06 LT after the arrival of the northward DRMM in the evening. Finally, rainfall over the mountain foothill region during the CENS inactive period (Fig. 8c) increased markedly in its intensity with a maximum at around $18 \mathrm{LT}$ and was maintained until the middle of the night (24 LT); thus, there was mostly no rainfall in the morning (06-12 LT). Meanwhile, that over the coastal region showed only weak and scattered echoes. Both northward and southward DRMMs were well identified. These characteristics observed by the 


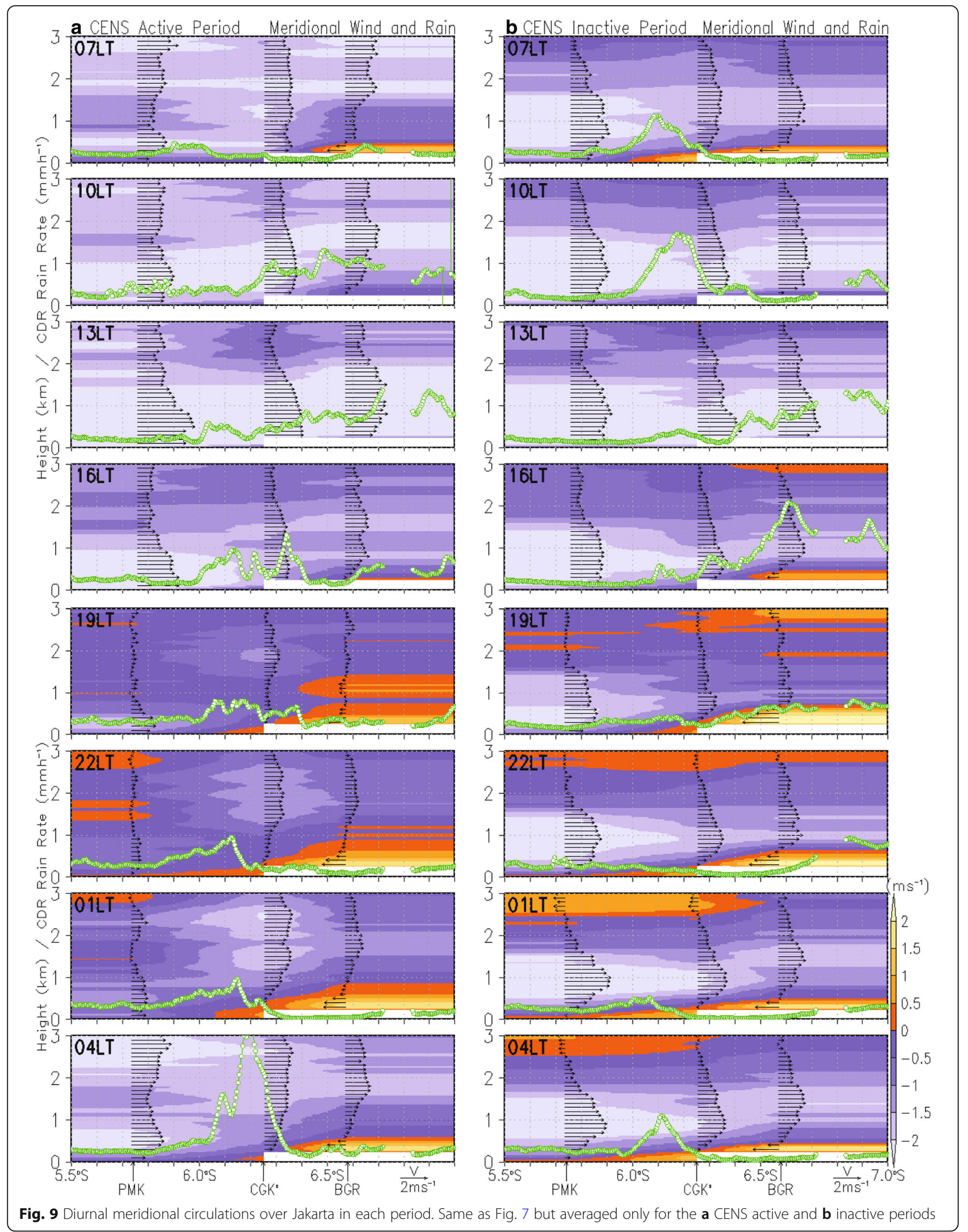


CDR were consistent with the results of AWS data, in particular for the results obtained at Bogor (Fig. 5d), i.e., the daily rainfall amount increased gradually from the beginning to the end of the campaign period with a phase delay of the diurnal rainfall peak from around noon (11 LT) to the evening (18 LT). Similar phase delay in the diurnal rainfall peak was also shown in both AWS data obtained at Pramuka (Fig. 5a) and the CDR observations from the evening (18 LT) to the middle of the night (24 LT), though it was less clear than that at Bogor.

The diurnal meridional circulations in the CENS active and inactive periods (Fig. 9) showed the following characteristics.

First, a rainfall peak over the mountain foothills around Bogor in the CENS inactive period (Fig. 9b) started to develop after $13 \mathrm{LT}$ and reached its maximum $\left(>2 \mathrm{~mm} \mathrm{~h}^{-1}\right)$ at $16 \mathrm{LT}$ when the land-breeze-like southerly wind close to the surface started to appear over Bogor, which converged with the intrusion of sea-breeze-like northerly wind. On the other hand, the rainfall peak around Bogor in the CENS active period (Fig. 9a) was formed earlier (13 LT) and was much smaller $\left(\sim 1 \mathrm{~mm} \mathrm{~h}^{-1}\right)$ in comparison to that in the CENS inactive period, and it then decreased early by $16 \mathrm{LT}$, a time in which the southerly near surface wind was not identified well, yet. The results suggest that the active CENS northerly wind close to the surface intruded deeply into the foothills until evening and then suppressed (or weakened) both the land-breeze generation and resulting local convections around Bogor after 13 LT, which must have been developed more at $16 \mathrm{LT}$ in the CENS inactive period as result of the sufficient convergence with the distinct land-breeze-like southerly wind.

Second, the land-breeze-like near surface southerly wind in the CENS inactive period (Fig. 9b) around Bogor intensified and reached its maximum $\left(>3 \mathrm{~m} \mathrm{~s}^{-1}\right)$ at 19-22 LT, and it was shallow at a height of less than $500 \mathrm{~m}$. The land-breeze-like southerly wind was identified even over the coastal sea (Pramuka) from 22 LT to 04 LT on the following day, and then it weakened and disappeared by 10 LT. On the other hand, that in the CENS active period (Fig. 9a) was weaker $\left(<2 \mathrm{~m} \mathrm{~s}^{-1}\right)$ and deeper, i.e., at a height of approximately $1 \mathrm{~km}$, during 19-22 LT. Although it reached over the coastal sea (Pramuka) once around 22 LT, it started to retreat back to land sooner (by $01 \mathrm{LT}$ ) in comparison to that in the inactive period.

Third, a rainfall peak was formed gradually around the coastline after 16 LT in the CENS active period (Fig. 9a), and then the rainfall reached its maximum at $04 \mathrm{LT}\left(>3 \mathrm{~mm} \mathrm{~h}^{-1}\right)$ with a weak but broad in extent rain area over the coastal sea when the land-breeze-like southerly wind was retreating across the coastline after reaching its maximum extent at $22 \mathrm{LT}$. On the other hand, rainfall around the coastline in the CENS inactive period (Fig. 9b) started to develop slowly after $01 \mathrm{LT}$, and then it reached a smaller peak $\left(<2 \mathrm{~mm} \mathrm{~h}^{-1}\right)$ at 10 LT after sunrise (06 LT) when the land-breeze-like southerly wind disappeared.

\section{Discussion}

\section{Cause of the northward DRMM in the nighttime}

Diurnal marches of coastal convections similar to those examined in this study have been widely identified over the Sumatera (e.g., Wu et al. 2003, 2009a; Mori et al. 2004; Sakurai et al. 2005; Yokoi et al. 2017), Kalimantan/Borneo (e.g., Houze et al. 1981; Ichikawa and Yasunari 2006; Wu et al. 2008), and Papua/New Guinea (e.g., Liberti et al. 2001; Zhou and Wang 2006; Ichikawa and Yasunari 2008) islands of the IMC and have been suggested to play an essential role in the formation of CHeRs (Mori et al. 2011). Sakurai et al. (2011) showed convergence between near surface easterly wind from dissipating local convective cells along the southwestern coastline of Sumatera Island and ambient southerly wind over the Indian Ocean, and this resulted in the successive generation of convective cells at the leading edge of precipitating systems that drove their offshore migration according to a case study of dual-Doppler radar observations. In addition, Mori et al. (2011) suggested that a seeder-feeder mechanism acts between leading-edges of westward spreading anvil clouds formed by local convections and eastward propagating large-scale MJO convections, which contributes to the offshore migration and re-development of the precipitating systems over the same region. On the contrary, Yokoi et al. (2017) recently studied radar and intensive sounding data obtained during the pre-YMC2015 campaign conducted around Bengkulu (3.86 $\left.\mathrm{S}, 102.33^{\circ} \mathrm{E}\right)$ on the southwestern coastline of Sumatera and found that shallow gravity waves generated by initial convections over the mountain foothill region in the daytime drove the convections toward the offshore in the late evening. Meanwhile, Wu et al. (2008) showed that the land-breeze (gravity current) circulation played an essential role in the nocturnal offshore migration of rainfall over Kalimantan/Borneo Island, and such events were mainly formed by evaporation cooling after rainfall in the evening over the island plain as well as nocturnal radiative cooling based on both satellite observations and numerical model simulations. Moreover, Ichikawa and Yasunari (2008) concluded that orography induced local circulation (i.e., mountain-valley breeze) and its interaction with large-scale monsoon winds were key factors for rainfall offshore propagation over New Guinea Island in addition to both land-sea breeze circulation and gravity waves.

Based on the observational results presented above, the northward (southward) DRMM is suggested to be 
driven by convections formed over converged frontlines ahead of land-breeze (sea breeze)-like southerly (northerly) wind close to the surface. Characteristics of southward DRMM in this study are consistent with the results reported by Hadi et al. (2002), which showed a southward traveling sea breeze in the daytime that formed along the northern coastline of Jawa Island, as identified by line-shaped clouds based on a series of GMS visible images displaying remarkable increases of surface relative humidity. Although their data were obtained in August, which corresponds to the dry season over Jakarta, the typical onset time of sea breeze over the coastline was 10 LT in their study, and it traveled southward with a speed of approximately $10 \mathrm{~km} \mathrm{~h}^{-1}$ $\left(2.8 \mathrm{~m} \mathrm{~s}^{-1}\right)$, which roughly matches with our results shown in Fig. 6b. The northward DRMM has been previously reported on observationally by Wu et al. (2007) during the CENS active phase in February and both Sulistyowati et al. (2014) and (Katsumata M, Mori S, Hamada JI, Hattori M, Syamsudin F, and Yamanaka MD (2018) Diurnal cycle over a coastal area of the maritime continent as derived by special networked soundings over Jakarta during HARIMAU2010. Unpublished) during the same campaign period of this study. In addition, Koseki et al. (2012) showed a northward DRMM in their control runs with a CT during November and March (major rainy season) with a traveling speed of approximately $4 \mathrm{~m} \mathrm{~s}^{-1}$ (it traveled $140 \mathrm{~km}$ in $9 \mathrm{~h}$, see their Fig. 9a), which was also roughly consistent with our results though they did not mention it explicitly. In addition, they concluded that nocturnal rainfall over the Jawa Sea formed by the convergence between the northerly monsoon with a CT and the nocturnal land breeze originating from the southern side of Jakarta (i.e., foothill and plain regions); this rainfall amount was much reduced when the CT was suppressed because of the weakened land-breeze "front" resulting in decreased northerly monsoon flow. Observational results in this study, however, as shown in Figs. 8 and 9, are not consistent with their model-simulated conclusions. A possible reason why there was an inconsistency is that they discussed the rainfall over the Jawa Sea apart from the coastline at a distance of approximately $30-100 \mathrm{~km}$, whereas that of our study was the area just over the coastline region (Figs. 7 and 9), which might involve other mechanisms as discussed briefly below.

In regard to the rainfall peaks that formed just over the coastline region as shown at 22-04 LT (04-10 LT) in Fig. 9a (Fig. 9b) when the land (sea) breeze was retreating (developing) across the coastline, specific processes may have worked to enhance them, e.g., land surface roughness decreased the northerly wind speed intruding from the Jawa Sea and this produced the coastal convergence (e.g., McPherson 1970; Pielke 1974;
Alestalo and Savijärvi 1985). In addition to this, other mechanisms that may have contributed as drivers of the DRMM over Jakarta, e.g., mountain-valley breeze circulations (e.g., Qian 2008), gravity waves (e.g., Wu et al. 2009b; Yokoi et al. 2017), self-sustaining and/or cumulus merger processes in mesoscale convective systems (e.g., Qian 2008; Sakurai et al. 2009, 2011), and the heat and moisture budgets studied by (Katsumata M, Mori S, Hamada JI, Hattori M, Syamsudin F, and Yamanaka MD (2018) Diurnal cycle over a coastal area of the maritime continent as derived by special networked soundings over Jakarta during HARIMAU2010. Unpublished) and their local transportation, should be examined in detail based on more case studies and/or by using numerical model simulations in future studies.

\section{Large-scale northerly wind influence on the southward DRMM in the daytime}

Hadi et al. $(2000,2002)$ showed that there are intrusions of sea breezes around 14 LT over Serpong, typically during the dry season, based on WPR observed data in 2000 , and the intrusions were identified well by the abrupt increase of relative humidity and decrease of both temperature and solar radiation as well as the arrival of northerly wind below a height of $1 \mathrm{~km}$. They also found, however, that northerly wind intrusions could be observed in the rainy season over Serpong, but these occurred much earlier at around 12 LT than those in the dry season. In addition, the sea-breeze intrusions occurred earlier on cloudy days even in the same dry season, though the intensity of sea-breeze circulation weakened accordingly. This seasonal variation was also identified climatologically by Araki et al. (2006) based on the same WPR observations, and the results were consistent with the time of surface maximum temperature at Serpong, i.e., 12 LT (14 LT) with a maximum temperature $30{ }^{\circ} \mathrm{C}\left(34{ }^{\circ} \mathrm{C}\right)$ in the rainy (dry) season. Hadi et al. (2002) suggested that the advanced arrival of northerly wind in both the rainy season and cloudy days in the dry season was not directly driven by typical sea-breeze circulations but closely related to cloud development over the plain region, i.e., inflow toward active convections that had already formed in the southern mountain foothill region, although Hadi et al. (2000) explained that the Kelvin-Helmholtz $(\mathrm{KH})$ instability in the sea breeze delayed its intrusion speed during clear days.

Results of sounding and CDR analyses in this study were consistent with those in previous studies, in particular those in the rainy season. In addition, contrasts between the CENS active and inactive periods, e.g., advanced (delayed) times of less (more) rainfall peaks over the land in the CENS active (inactive) period, were similar to those between both rainy and dry seasons and 
cloudy and clear sky days during the dry season. Predominant northwesterly wind in the CENS active period resulted after the eastward passage of the MJO convention center (Fig. 2), which masked over the local sea-breeze circulation in the daytime, and it is suggested here that this suppresses or makes it difficult to maintain local convections over the land, which develop mainly until the evening in the CENS inactive period. The assumption is that enhancement of the northerly wind in the daytime of the CENS active period is accompanied by thermally driven local circulation that is suppressed soon after noon because of the much greater extent in cloudiness (Araki et al. 2006). This idea is also consistent with the results of Qian et al. (2010) in that weakening of northwesterly monsoon wind over the IMC amplifies the local diurnal cycle of land-sea breezes and mountain-valley winds over the western part of Jawa Island, which produces more rainfall over the mountainous region. Another possibility is that abundant rainfall over the coastal region in the night to early morning period might consume water vapor much in advance so that it would not be transported to the plain and foothill regions, which could make the atmosphere unstable in the daytime. Further studies that examine the spatiotemporal variation of moisture and local atmospheric stability characteristics during the CENS active and inactive periods will be required to settle these questions. For example, zonal variations of convective activity, which were predominant in the CENS active period with strong northwesterly synoptic winds, namely, eastward moving rain echoes mostly originating from Sumatera Island (figure not shown), might play another important role in the generation of nocturnal rainfall over the coastal area of the Jawa Sea; these provide a good contrast to the DRMMs under the remarkable local meridional circulations during the CENS inactive period.

\section{Conclusions}

This paper presented an overview of the HARIMAU2010 campaign focusing on convective activity with the DRMM over Jakarta, Jawa Island, in the IMC based on 1-month intensive observations by a CDR and data from a multi-point sounding array that were first collected in this area during 00 UTC on 16 January to 24 UTC on 14 February 2010. The campaign period corresponded to a phase after large-scale MJO active convections passed over Jakarta (MJO inactive phase). The CENS intruded into the Jawa Sea with a CT in the beginning of the period (CENS active period: 16-25 January), and then it started to retreat (transition period: 26 January-04 February); finally, few signs of it could be detected (CENS inactive period: 05-14 February). The results of this study imply that (1) rainfall over Jakarta has the nature of DRMM during the MJO inactive phase at least, (2) the DRMM is suggested to be driven primarily by "land-breeze"-like local meridional circulation, and (3) the meridional spatiotemporal variation of rainfall over Jakarta is controlled by activities of both the CENS and CT over the Jawa Sea, consequently.

Daily and diurnal variations of surface rainfall observed by AWSs at all sounding and CDR/WPR sites showed distinctly different characteristics, in particular for those in the meridional directions among the northern (Pramuka: coastal sea), central (Serpong: plain), and southern (Bogor: mountain foothills) sides of Jakarta. Rainfall over the coastal sea had a gentle peak in the night followed by a weak one until the next morning, whereas that over the mountain foothills had a pronounced peak in the evening and was delayed gradually from the beginning to the end of the period with increases in its intensity. The CDR confirmed those characteristics formed by the meridional marches of diurnal rainfall (DRMMs), which traveled northward (southward) in the nighttime (daytime) over Jakarta with speed of approximately $5 \mathrm{~m} \mathrm{~s}^{-1}\left(2 \mathrm{~m} \mathrm{~s}^{-1}\right)$. In addition, spatiotemporal variation of meridional winds over Jakarta based on the intensive soundings showed a land-sea-breeze-like circulation close to the surface, namely, the development and expansion of land-breezelike southerly wind from the mountain foothill region after sunset (19 LT), and then an increase of its intensity and intrusion into the Jawa Sea occurred across the coastline in the nighttime (22 LT) followed by its retreat back to the land region early the next morning (04 LT). Both results suggest that nocturnal rainfall formed over the front of land-breeze-like southerly wind close to the surface and traveled from the mountain foothill region with evening showers toward the coastal region through the night coincident with the meridional advance and retreat of the front. Furthermore, the observational results suggested that the northward (southward) DRMM was driven primarily by convections formed over the converged frontline ahead of land-breeze (sea-breeze)-like southerly (northerly) wind close to the surface. Although the nature of the DRMM was fundamentally consistent with the results in a previous numerical simulation study (Koseki et al. 2012), other mechanisms that may play a contributing role as drivers of the DRMM over Jakarta, e.g., mountain-valley breeze circulations, gravity waves, selfsustaining processes in mesoscale convective systems, and coastal convergence effects, as well as heat and moisture budgets and their local transportation, should be examined in detail in future studies.

The DRMM as well as the local meridional circulation showed distinct behaviors in the CENS active and inactive periods, which can be summarized as follows. (1) Rainfall over the mountain foothill region peaked weaker (stronger) and earlier (later) around 12-13 LT (16-18 LT) in the CENS active (inactive) period. On the other hand, (2) that 
over the Jawa Sea peaked quite stronger (weaker) and earlier (later) around 04 LT (10 LT) in the CENS active period. (3) Land-breeze-like southerly wind close to the surface was weaker (stronger) and stayed over the Jawa Sea for a shorter (longer) time until around 04 LT (07 LT) after crossing the coastline in the CENS active (inactive) period. Consequently, these results explained the unique characteristics in daily and diurnal variations of rainfall at the mountain hill region (Bogor) well (Fig. 5d). Predominant northerly wind in the CENS active period, which masked over the local sea-breeze circulation in the daytime, may suppress or make it difficult to maintain local convections over the land, which develop mainly until the evening in the CENS inactive period. Assumptions speculated from previous studies, e.g., suppression of afternoon rain showers by greater extents of cloudiness and lesser supplies of precipitable water vapor from the coastal to foothill regions due to the consumption by abundant nocturnal rainfall in the CENS active period also, should be studied by examining the spatiotemporal variation of moisture and local atmospheric stability characteristics during the CENS active and inactive periods. This would help to settle these questions in the next phase of research. In addition, WPR and another surface observation dataset, which were not analyzed in this paper, should be utilized for case studies in the next step to focus more on the mesoscale structure of diurnally developed convections together with other data, for example, spatiotemporal variations of echo top heights obtained by the CDR (Katsumata M, Mori S, Hamada JI, Hattori M, Syamsudin F, and Yamanaka MD (2018) Diurnal cycle over a coastal area of the maritime continent as derived by special networked soundings over Jakarta during HARIMAU2010. Unpublished) and intensive atmospheric soundings during the campaign to compare with the results of previous studies based on single WPR observations. Furthermore, quantitative analyses of rainfall derived from CDR will be needed for hydrometeorological studies over Jakarta involving comparisons with ground-based rain gauge data as well as GSMaP satellite observations.

Note that the HARIMAU2010 campaign was the first to have conducted comprehensive meteorological research observations over the "greater Jakarta" region with an intensive atmospheric sounding network. The CDR used in the campaign continued its observations until the end of May 2013. After that, BMKG started operational C-band Doppler radar observations at Tangerang $\left(6.13^{\circ} \mathrm{S}\right.$, $\left.106.66^{\circ} \mathrm{E}\right)$, which covered the "greater Jakarta" region, and this effort continues at present.

\section{Endnotes}

${ }^{1}$ We experimentally applied a typical rain attenuation correction of $0.0018 \mathrm{R}^{1.05}\left(\mathrm{~dB} \mathrm{~km}^{-1}\right)$ for C-band (wavelength $=5 \mathrm{~cm}$ ) radars (Doviak and Zrnić 1993) to the obtained data and found that there is no serious difference between the original and corrected data. For example in Fig. 3e, total echo coverage (convective rain area fraction) of the original and corrected data during the campaign period were $13.0 \%(7.7 \%)$ and $13.2 \%$ (7.5\%), respectively.

${ }^{2}$ Although Karawang is located at a higher latitude than Serang, distances from the nearest coastline to Karawang are approximately $20 \mathrm{~km}$. It is not so far from these locations to Cengkareng and Serang (approximately $5 \mathrm{~km}$ and $10 \mathrm{~km}$, respectively), the "coastal land" stations, in comparison with the distances to Serpong and Bogor (approximately $40 \mathrm{~km}$ and $50 \mathrm{~km}$, respectively), the "plain" and "mountain foothill" stations, respectively. In addition, Karawang is located over a large open field facing the northern coastline and there are only broad paddy fields and ponds for cultivations between Karawang and the coastline, i.e., there are no specific obstacles that would disturb meridional winds in the lower troposphere. It is also a quite different environment than Serpong (plain) and/or Bogor (mountain foothills) because there is the large downtown area of Jakarta with its numerous skyscrapers between the coastline and these stations. Consequently, we deal with Karwang as the representative location of the eastern "coastal land" in the present study.

\section{Abbreviations}

AMSL: Above mean sea level; AWS: Automatic weather station; Az: Azimuth angle; BLR: Boundary layer radar; BMKG: Agency for Meteorology, Climatology and Geophysics, Indonesia; BMRC: Bureau of Meteorology Research Centre; BPPT: Agency for the Assessment and Application of Technology, Indonesia; BSW: Blended sea winds; CDR: C-band Doppler radar; CENS: Cross-equatorial northerly surge; CGK: A three-letter code for the Soekarno-Hatta International Airport, Indonesia; CHeR: Coastal heavy rainband; CSR: Clutter-to-signal ratio; CT: Cold tongue; DEM: Digital elevation model; DRMM: Diurnal rainfall meridional march; EOS: Earth Observation System; GMS: Geostationary Meteorological Satellite; GNSS: Global navigation satellite system; GSMaP: Global satellite mapping of precipitation; GTOPO30: Global 30 arcsecond elevation; HARIMAU: Hydrometeorological Array for ISV-Monsoon Automonitoring (name of a project); IMC: Indonesian maritime continent: IRIS: Interactive radar information system; ISV: Intraseasonal variation; JABODETABEK: Jakarta, Bogor, Depok, Tangerang, and Bekasi; JAXA: Japanese Aerospace Exploration Agency; JEPP: Japanese EOS Promotion Plan (name of a project/fund); JFY: Japanese fiscal year; JICA: Japan International Cooperation Agency; JMA: Japan Meteorological Agency; ISPS: Japan Society for the Promotion of Science (name of a fund); IST: Japan Science and Technology Agency; KAKENHI: Grants-in-Aid for Scientific Research (name of a fund);

KH: Kelvin-Helmholtz; LAPAN: National Institute of Aeronautics and Space; LOG: Log receiver signal-to-noise ratio; LT: Local time; MAHASRI: Monsoon Asian Hydro-atmosphere Scientific Research and Prediction Initiative (name of a project); MCCOE: Maritime Continent Center of Excellence; MJO: Madden-Julian oscillation; MRI: Meteorological Research Institute, Japan; NCEP: National Centers for Environmental Prediction, USA; NHM: Nonhydrostatic model; NOAA: National Oceanic and Atmospheric Administration, USA; NRT: Near real-time; OISST: Optimum Interpolation Sea Surface Temperature; PI: Principal investigator; PMM: Precipitation Measuring Mission (name of a project/fund); PRF: Pulse repetition frequency; PWV: Precipitable water vapor; QuikSCAT: Quick Scatterometer; RMM: Real-time multivariate MJO; SATREPS: Science and Technology Research Partnership for Sustainable Development (name of a project /fund); SCS: South China Sea; SQI: Signal quality index; SST: Sea surface 
temperature; TRMM: Tropical Rainfall Measuring Mission; U.S.: United States of America; UTC: Coordinated universal time; WIB: West Indonesian standard time; WPR: Wind profiling radar; YMC: Years of the Maritime Continent (name of a project); Ze: Zenith angle

\section{Acknowledgements}

The authors express their thanks to all who were engaged in the HARIMAU2010 campaign observations, in particular, the young scientists and engineers from BPPT, BMKG, LAPAN, and Kyoto University. Thanks are also extended to Professor Jun Matsumoto of Tokyo Metropolitan University who encouraged the JEPP_ HARIMAU and SATREPS-MCCOE projects as a part of Monsoon Asian Hydroatmosphere Scientific Research and Prediction Initiative (MAHASRI) activities in Indonesia and offered valuable comments on the manuscript.

\section{Funding}

This work, including the HARIMAU2010 field campaign and analyses of the data obtained, was supported mainly by the Japanese Earth Observation System (EOS) Promotion Program (JEPP) Hydrometeorological Array for ISVMonsoon Automonitoring (HARIMAU) project (JFY2005-2009, PI: Manabu D. Yamanaka) and the Science Technology Research Partnership for Sustainable Development (SATREPS) Maritime Continent Center of Excellence (MCCOE) project (JFY2009-2013, PI: Manabu D. Yamanaka) of the Japan Science and Technology Agency (JST)/Japan International Cooperation Agency (JICA). In addition, this work was partially supported by JSPS (Japan Society for the Promotion of Science) KAKENHI Grant Numbers JP22310115 (JFY2010-2012, PI: Shuichi Mori), JP25350515 (JFY2013-2015, PI: Shuichi Mori), JP 23340142 (JFY2011-2013, PI: Hiroyuki Hashiguchi), and JP15K01167 (JFY2015-2017, PI: Hamada Jun-Ichi), and the Japan Aerospace Exploration Agency (JAXA) Precipitation Measuring Mission (PMM) 6th and 7th Research Announcements (JFY2010-2012, JFY2013-2015, Pl: Shuichi Mori).

\section{Availability of data and materials}

The datasets analyzed in the current study are available from the corresponding author on request.

\section{Authors' contributions}

SM proposed the topic of this study, including both the types of observations and analyses. SM and FS led the onsite observations by the Japanese and Indonesian teams, respectively. All authors contributed to the design, preparation, and execution of the HARIMAU2010 field campaign as well as discussions of the results presented in the final manuscript. MDY was the principal investigator of the JEPP-HARIMAU and SATREPS-MCCOE projects. All authors read and approved the final manuscript.

\section{Competing interests}

The authors declare that they have no competing interests.

\section{Publisher's Note}

Springer Nature remains neutral with regard to jurisdictional claims in published maps and institutional affiliations.

\footnotetext{
Author details

'Japan Agency for Marine-Earth Science and Technology (JAMSTEC), 2-15 Natsushima-cho, Yokosuka 237-006, Japan. ${ }^{2}$ Research Center for Climatology and Department of Geography, Tokyo Metropolitan University, 1-1 Minami-Osawa, Hachioji 192-0397, Japan. ${ }^{3}$ Present Address: National Institute for Agro-Environmental Sciences (NIAES), National Agriculture and Food Research Organization (NARO), 3-1-3 Kan-non-dai, Tsukuba 305-8604, Japan. ${ }^{4}$ Graduate School of Advanced Science and Technology, Kumamoto University, 2-39-1 Kurokami, Chuo-ku, Kumamoto 860-8555, Japan. ${ }^{5}$ Research Institute for Sustainable Humanosphere (RISH), Kyoto University, Gokasho, Uji 611-0011, Japan. ${ }^{6}$ Center for Regional Resources Development Technology (PTPSW), Agency for the Assessment and Application of Technology (BPPT), J. Raya Puspiptek, South Tangerang 15314, Indonesia. ${ }^{7}$ Atmosphere and Ocean Research Institute (AORI), The University of Tokyo, 5-1-5, Kashiwanoha, Kashiwa-shi, Chiba 277-8564, Japan. ${ }^{8}$ School of Earth Sciences, The University of Melbourne, Victoria 3010, Australia. ${ }^{9}$ Space Science Center, National Institute of Aeronautics and Space (LAPAN), JI. Dr. Junjunan, Bandung 40173, Indonesia. ${ }^{10}$ Research Institute for Humanity and Nature (RIHN), Kamigamo-motoyama, Kita-ku, Kyoto 603-8047, Japan. ${ }^{11}$ Kobe University, Rokkodai-cho, Nada-ku, Kobe 657-8501, Japan.
}

Received: 22 August 2017 Accepted: 11 August 2018 Published online: 03 September 2018

\section{References}

Alestalo M, Savijärvi H (1985) Mesoscale circulations in a hydrostatic model: coastal convergence and orographic lifting. Tellus 37A:156-162 https://doi. org/10.1111/j.1600-0870.1985.tb00277.x

Araki R, Yamanaka MD, Murata F, Hashiguchi H, Oku Y, Sribimawati T, Kudsy M, Renggono F (2006) Seasonal and interannual variations of diurnal cycles of wind and cloud activity observed at Serpong, west Jawa, Indonesia. J Meteor Soc Japan 84A:171-194 https://doi.org/10.2151/jmsj.84A.171

Banzon V, Smith TM, Chin TM, Liu C, Hankins W (2016) A long-term record of blended satellite and in situ sea-surface temperature for climate monitoring, modeling and environmental studies. Earth Syst Sci Data 8:165-176 https:// doi.org/10.5194/essd-8-165-2016

Belgaman HA, Ichiyanagi K, Tanoue M, Suwarman R (2016) Observational research on stable isotopes in precipitation over Indonesian maritime continent. J Japanese Assoc Hydrol Sci 46:7-28 https://doi.org/10.4145/jahs.46.7

Doviak RJ, Zrnić DS (1993) Doppler radar and weather observations, 2nd edn. Academic Press, San Diego, p 562 https://doi.org/10.1016/C2009-0-22358-0

Fudeyasu H, Ichiyanagi K, Yoshimura K, Mori S, Sakurai N, Hamada Jl, Yamanaka MD, Matsumoto J, Syamsudin F (2011) Effects of large-scale moisture transport and mesoscale processes on precipitation isotope ratios observed at Sumatera, Indonesia. J Meteor Soc Japan 89A:49-59 https://doi.org/10. 2151/jmsj.2011-A03

Fujita M, Yoneyama K, Mori S, Nasuno T, Satoh M (2011) Diurnal convection peaks over the eastern Indian Ocean off Sumatra during different MJO phases. J Meteor Soc Japan 89A:317-330 https://doi.org/10.2151/jmsj.2011-A22

Hadi TW, Horinouchi T, Tsuda T, Hashiguchi H, Fukao S (2002) Sea-breeze circulation over Jakarta, Indonesia: a climatology based on boundary layer radar observations. Mon Wea Rev 130:2153-2166 https://doi.org/10.1175/ 1520-0493(2002)130<2153:SBCOJ>2.0.CO;2

Hadi TW, Tsuda T, Hashiguchi H, Fukao S (2000) Tropical sea-breeze circulation and related atmospheric phenomena observed with L-band boundary layer radar in Indonesia. J Meteor Soc Japan 78:123-140 https://doi.org/10.2151/ jmsj1965.78.2_123

Hamada Jl, Mori S, Yamanaka MD, Haryoko U, Lestari S, Sulistyowati R, Syamsudin F (2012) Interannual rainfall variability over northwestern Jawa and its relation to the Indian Ocean dipole and El Nino southern-oscillation events. SOLA 8:69-72 https://doi.org/10.2151/sola.2012-018

Hamada JI, Yamanaka MD, Matsumoto J, Fukao S, Winarso PA, Sribimawati T (2002) Spatial and temporal variations of the rainy season over Indonesia and their link to ENSO. J Meteor Soc Japan 80:285-310 https://doi.org/10.2151/jmsj.80.285

Hamada JI, Yamanaka MD, Mori S, Tauhid YI, Sribimawati T (2008) Differences of rainfall characteristics between coastal and mountainous areas of Sumatera, Indonesia. J Meteor Soc Japan 86:593-611 https://doi.org/10.2151/jmsj.86.593

Hashiguchi H, Fukao S, Tsuda T, Yamanaka MD, Tobing DL, Sribimawati T, Harijono SWB, Wiryosumarto H (1995c) Observations of the planetary boundary layer over equatorial Indonesia with an L-band clear-air Doppler radar: initial results. Radio Sci 30:1043-1054 https://doi.org/10. 1029/95RS00653

Hashiguchi H, Tsuda T, Fukao S, Yamanaka MD, Harijono SWB, Wiryosumarto H (1995a) Boundary layer radar observations of the passage of the convection center over Serpong, Indonesia $\left(6^{\circ} \mathrm{S}, 107^{\circ} \mathrm{E}\right)$ during the TOGA-COARE intensive observation period. J Meteor Soc Japan 73:535-548 https://doi.org/ 10.2151/jmsj1965.73.2B_535

Hashiguchi H, Yamanaka MD, Tsuda T, Yamamoto M, Nakamura T, Adachi T, Fukao S, Sato T, Tobing DL (1995b) Diurnal variations of the planetary boundary layer observed with an L-band clear-air Doppler radar. BoundaryLayer Meteor 74:419-424 https://doi.org/10.1007/BF00712381

Hattori M, Mori S, Matsumoto J (2011) The cross-equatorial northerly surge over the maritime continent and its relationship to precipitation patterns. J Meteor Soc Japan 89A:27-47 https://doi.org/10.2151/jmsj.2011-A02

Houze RA, Geotis SG, Marks FD, West AK (1981) Winter monsoon convection in the vicinity of North Borneo. Part I: structure and time variation of the clouds and precipitation. Mon Wea Rev 109:1595-1614 https://doi.org/10.1175/15200493(1981)109<1595:WMCITV>2.0.CO;2

Ichikawa H, Yasunari T (2006) Time-space characteristics of diurnal rainfall over Borneo and surrounding oceans as observed by TRMM-PR. J Clim 19:1238-1260 https://doi.org/10.1175/JCLI3714.1 
Ichikawa H, Yasunari T (2008) Intraseasonal variability in diurnal rainfall over New Guinea and the surrounding oceans during austral summer. J Clim 21:2852-2868 https://doi.org/10.1175/2007JCLI1784.1

Kalnay E, Kanamitsu M, Kistler R, Collins W, Deaven D, Gandin L, Iredell M, Saha S, White G, Woollen J, Zhu Y, Leetmaa A, Reynolds R, Chelliah M, Ebisuzaki W, Higgins W, Janowiak J, Mo KC, Ropelewski C, Wang J, Jenne R, Joseph D (1996) The NCEP/NCAR 40-year reanalysis project. Bull Amer Meteor Soc 77:437-471 https://doi.org/10.1175/1520-0477(1996)077<0437:TNYRP>2.0.CO;2

Kamimera H, Mori S, Yamanaka MD, Syamsudin F (2012) Modulation of diurnal rainfall cycle by the Madden-Julian oscillation based on one-year continuous observations with a meteorological radar in West Sumatera. SOLA 8:111-114 https://doi.org/10.2151/sola.2012-028

Kawashima M, Fujiyoshi Y, Ohi M, Mori S, Sakurai N, Abe Y, Harjupa W, Syamsudin F, Yamanaka MD (2011) Case study of an intense wind event associated with a mesoscale convective system in west Sumatera during the HARIMAU2006 campaign. J Meteor Soc Japan 89A:239-257 https://doi.org/10.2151/jmsj.2011-A15

Koseki S, Koh TY, Teo CK (2012) Effects of the cold tongue in the South China Sea on the monsoon, diurnal cycle and rainfall in the maritime continent. Q J R Meteorol Soc 139(675):1566-1582 https://doi.org/10.1002/qj.2052

Liberti GL, Chéruy F, Desbois M (2001) Land effect on the diurnal cycle of clouds over the TOGA COARE area, as observed from GMS IR data. Mon Wea Rev 129 1500-1517 https://doi.org/10.1175/1520-0493(2001)129<1500:LEOTDC > 2.0.CO;2

Madden RA, Julian PR (1972) Description of global-scale circulation cells in the tropics with a 40-50 day period. J Atmos Sci 29:1109-1123 https://doi.org/ 10.1175/1520-0469(1972)029<1109:DOGSCC > 2.0.CO;2

McPherson RD (1970) A numerical study of the effect of a coastal irregularity on the sea breeze. J Appl Meteorol 9:767-777 https://doi.org/10.1175/15200450(1970)009<0767:ANSOTE>2.0.CO;2

Mori S, Hamada Jl, Sakurai N, Fudeyasu H, Kawashima M, Hashiguchi H, Syamsudin F, Arbain AA, Sulistyowati R, Matsumoto J, Yamanaka MD (2011) Convective systems developed along the coastline of Sumatera Island, Indonesia, observed with an X-band Doppler radar during the HARIMAU2006 campaign. J Meteor Soc Japan 89A:61-81 https://doi.org/10.2151/jmsj.2011-A04

Mori S, Hamada Jl, Tauhid YI, Yamanaka MD, Okamoto N, Murata F, Sakurai N, Hashiguchi H, Sribimawati T (2004) Diurnal land-sea rainfall peak migration over Sumatera Island, Indonesian maritime continent, observed by TRMM satellite and intensive rawinsondes soundings. Mon Wea Rev 132:2021-2039 https://doi.org/10.1175/1520-0493(2004)132<2021:DLRPMO>2.0.CO;2

Mori S, Hamada JI, Yamanaka MD, Kodama YM, Kawashima M, Shimomai T, Shibagaki Y, Hashiguchi H, Sribimawati T (2006) Vertical wind characteristics in precipitating cloud systems over west Sumatera, Indonesia, observed with equatorial atmosphere radar: case study of 23-24 April 2004 during the first CPEA campaign period. J Meteor Soc Japan 84A:113-131 https://doi.org/10. 2151/jmsj.84A.113

Ogino SY, Yamanaka MD, Mori S, Matsumoto J (2016) How much is the precipitation amount over the tropical coastal region? J Clim 29:1231-1236 https://doi.org/ 10.1175/JCLI-D-15-0484.1

Ogino SY, Yamanaka MD, Mori S, Matsumoto J (2017) Tropical coastal dehydrator in global atmospheric water circulation. Geophys Res Lett 44:11636-11643 https://doi.org/10.1002/2017GL075760

Oigawa M, Matsuda T, Tsuda T, Noersomadi (2017) Coordinated observation and numerical study on a diurnal cycle of tropical convection over a complex topography in West Java, Indonesia. J Meteor Soc Japan 95:261-281 https:// doi.org/10.2151/jmsj.2017-015

Okamoto K, Iguchi T, Takahashi N, Iwanami K, Ushio T (2005) The global satellite mapping of precipitation (GSMaP) project, 25th IGARSS Proceedings, pp 3414-3416

Pielke RA (1974) A three-dimensional numerical model of the sea breezes over South Florida. Mon Wea Rev 102:115-139 https://doi.org/10.1175/15200493(1974)102<0115:ATDNMO>2.0.CO;2

Qian J (2008) Why precipitation is mostly concentrated over islands in the maritime continent. J Atmos Sci 65:1428-1441 https://doi.org/10.1175/2007JAS2422.1

Qian J, Robertson AW, Moron V (2010) Interactions among ENSO, the monsoon, and diurnal cycle in rainfall variability over Java, Indonesia. J Atmos Sci 67: 3509-3524 https://doi.org/10.1175/2010JAS3348.1

Ramage CS (1968) Role of a tropical "maritime continent" in the atmospheric circulation. Mon Wea Rev 96:365-370 https://doi.org/10.1175/15200493(1968)096<0365:ROATMC>2.0.CO;2

Realini E, Sato K, Tsuda T, Susilo, Manik T (2014) An observation campaign of precipitable water vapor with multiple GPS receivers in western Java, Indonesia. Prog Earth Planet Sci 1:17 https://doi.org/10.1186/2197-4284-1-17
Renggono F, Hashiguchi H, Fukao S, Yamanaka MD, Ogino SY, Okamoto N, Murata F, Harijono SWB, Kudsy M, Kartasasmita M, Ibrahim G (2001) Precipitating clouds observed by 1.3-GHz L-band boundary layer radars in equatorial Indonesia. Ann Geophys 19:889-897 https:/doi.org/10.5194/angeo-19-889-2001

Saito K, Fujita T, Yamada Y, Ishida J, Kumagai Y, Aranami K, Ohmori S, Nagasawa R, Kumagai S, Muroi C, Kato T, Eito H, Yamazaki Y (2006) The operational JMA nonhydrostatic mesoscale model. Mon Wea Rev 134:1266-1298 https://doi. org/10.1175/MWR3120.1

Sakurai N, Kawashima M, Fujiyoshi Y, Hashiguchi H, Shimomai T, Mori S, Hamada Il, Murata F, Yamanaka MD, Tauhid Yl, Sribimawati T, Suhardi B (2009) Internal structure of migratory cloud system with diurnal cycle over Sumatera Island during CPEA-I campaign. J Meteor Soc Japan 87:157-170 https://doi.org/10.2151/jmsj.87.157

Sakurai N, Mori S, Kawashima M, Fujiyoshi Y, Hamada Jl, Shimizu S, Fudeyasu H, Tabata Y, Harjupa W, Hashiguchi H, Yamanaka MD, Matsumoto J, Emrizal, Syamsudin F (2011) Migration process and 3D wind field of precipitation systems associated with a diurnal cycle in west Sumatera: dual Doppler radar analyses during the HARIMAU2006 campaign. J Meteor Soc Japan 89:341-361 https://doi.org/10.2151/jmsj.2011-404

Sakurai N, Murata F, Yamanaka MD, Mori S, Hamada Jl, Hashiguchi H, Tauhid Yl, Sribimawati T, Suhardi B (2005) Diurnal cycle of cloud system migration over Sumatera Island. J Meteor Soc Japan 83:835-850 https://doi.org/10.2151/jmsj. 83.835

Schumacher C, Houze RA Jr (2003) Stratiform rain in the tropics as seen by the TRMM precipitation radar. J Clim 16:1739-1756 https://doi.org/10.1175/ 1520-0442(2003)016<1739:SRITTA > 2.0.CO:2

Shibagaki Y, Kozu T, Shimomai T, Mori S, Murata F, Fujiyoshi Y, Hashiguchi H, Fukao S (2006a) Evolution of a super cloud cluster and the associated wind fields observed over the Indonesian maritime continent during the first CPEA campaign. J Meteor Soc Japan 84A:19-31 https://doi.org/10.2151/jmsj.84A.19

Shibagaki Y, Shimomai T, Kozu T, Mori S, Fujiyoshi Y, Hashiguchi H, Yamamoto MK, Fukao S, Yamanaka MD (2006b) Multi-scale convective systems associated with an intraseasonal oscillation over the Indonesian maritime continent. Mon Wea Rev 134:1682-1696 https://doi.org/10.1175/MWR3152.1

Steiner M, Houze RA Jr, Yuter SE (1995) Climatological characterization of threedimensional storm structure from operational radar and rain gauge data. J Appl Meteorol 34:1978-2007 https://doi.org/10.1175/1520-0450(1995)034<1978: CCOTDS $>2.0 \cdot \mathrm{CO}: 2$

Sulistyowati R, Hapari RI, Syamsudin F, Mori S, Oishi ST, Yamanaka MD (2014) Rainfall-driven diurnal variations of water level in Ciliwung River, West Jawa, Indonesia. SOLA 10:141-144 https://doi.org/10.2151/sola.2014-029

Trilaksono NJ, Otsuka S, Yoden S (2012) A time-lagged ensemble simulation on the modulation of precipitation over west Java in January-February 2007. Mon Wea Rev 140:601-616 https://doi.org/10.1175/MWR-D-11-00094.1

Trilaksono NJ, Otsuka S, Yoden S, Saito K, Hayashi S (2011) Dependence of model-simulated heavy rainfall on the horizontal resolution during the Jakarta flood event in January-February 2007. SOLA 7:193-196 https://doi. org/10.2151/sola.2011-049

U.S. Geological Survey (1993) Digital Elevation Models, Data User Guide 5, Reston, 53 pp http://pubs.er.usgs.gov/publication/70038376

Vaisala (2008) RVP8 Digital IF Receiver/Doppler Signal Processor User's Manual. Vaisala Inc., p 437 ftp://ftp.sigmet.com/outgoing/releases/8.12.1/RHEL4/iris/man.tgz

van Bemmelen W (1922) Land- und Seebrise in Batavia. Beitr Phys Frei Atmos 10: 169-177 (in German)

Wheeler MC, Hendon HH (2004) An all-season real-time multivariate MJO index: development of an index for monitoring and prediction. Mon Wea Rev 132 1917-1932 https://doi.org/10.1175/1520-0493(2004)132<1917:AARMMI>2.0.CO;2

Wu PM, Arbain AA, Mori S, Hamada Jl, Hattori M, Syamsudin F, Yamanaka MD (2013) The effects of an active phase of the Madden-Julian oscillation on the extreme precipitation event over western Jawa Island in January 2013. SOLA 9:79-83 https://doi.org/10.2151/sola.2013-018

Wu PM, Hamada JI, Mori S, Tauhid YI, Yamanaka MD, Kimura F (2003) Diurnal variation of precipitable water over a mountainous area of Sumatra Island. J Appl Meteorol 42:1107-1115 https://doi.org/10.1175/15200450(2003)042<1107:DVOPWO>2.0.CO;2

Wu PM, Hamada JI, Yamanaka MD, Matsumoto J, Hara M (2009b) The impact of orographically-induced gravity wave on the diurnal cycle of rainfall over Southeast Kalimantan Island. Atmos Ocean Sci Lett 2:35-39 https://doi.org/ 10.1080/16742834.2009.11446773

Wu PM, Hara M, Fudeyasu H, Yamanaka MD, Matsumoto J, Syamsudin F, Sulistyowati R, Djajadihardja YS (2007) The impact of trans-equatorial 
monsoon flow on the formation of repeated torrential rains over Java Island. SOLA 3:93-96 https://doi.org/10.2151/sola.2007-024

Wu PM, Hara M, Hamada J, Yamanaka MD, Kimura F (2009a) Why a large amount of rain falls over the sea in the vicinity of western Sumatra Island during nighttime. J Appl Meteor Climatol 48:1345-1361 https://doi.org/10.1175/2009JAMC2052.1

Wu PM, Yamanaka MD, Matsumoto J (2008) The formation of nocturnal rainfall offshore from convection over western Kalimantan (Borneo) Island. J Meteor Soc Japan 86A:187-203 https://doi.org/10.2151/jmsj.86A.187

Yamanaka MD (2016) Physical climatology of Indonesian maritime continent: an outline to comprehend observational studies. Atmos Res 178-179:231-259 https://doi.org/10.1016/j.atmosres.2016.03.017

Yamanaka MD, Mori S, Wu PM, Hamada Jl, Sakurai N, Hashiguchi H, Yamamoto MK, Shibagaki Y, Kawashima M, Fujiyoshi Y, Shimomai T, Manik T, Erlansyah SW, Tejasukmana B, Syamsudin F, Djajadihardia YS, Anggadiredja JT (2008) HARIMAU radar-profiler network over Indonesian maritime continent: a GEOSS early achievement for hydrological cycle and disaster prevention. J Disaster Res 3:78-88 https://doi.org/10.20965/jdr.2008.p0078

Yamanaka MD, Ogino SY, Wu PM, Hamada JI, Mori S, Matsumoto J, Syamsudin F (2018) Maritime continent coastlines controlling Earth's climate. Prog Earth Planet Sci 5:21 https://doi.org/10.1186/s40645-018-0174-9

Yokoi S, Mori S, Katsumata M, Geng B, Yasunaga K, Syamsudin F, Nurhayati, Yoneyama K (2017) Diurnal cycle of precipitation observed in the western coastal area of Sumatra Island: offshore preconditioning by gravity waves. Mon Wea Rev 145:3745-3761 https://doi.org/10.1175/MWR-D-16-0468.1

Zhang HM, Bates JJ, Reynolds RW (2006) Assessment of composite global sampling: sea surface wind speed. Geophys Res Lett 33:L17714 https://doi. org/10.1029/2006GL027086

Zhou L, Wang Y (2006) Tropical rainfall measuring mission observation and regional model study of precipitation diurnal cycle in the New Guinean region. J Geophys Res 111:D17104 https://doi.org/10.1029/2006JD007243

\section{Submit your manuscript to a SpringerOpen ${ }^{\circ}$ journal and benefit from:}

- Convenient online submission

- Rigorous peer review

- Open access: articles freely available online

High visibility within the field

- Retaining the copyright to your article

Submit your next manuscript at $\boldsymbol{\nabla}$ springeropen.com 